\title{
Assessing ecosystem services for informing land-use decisions: a problem- oriented approach
}

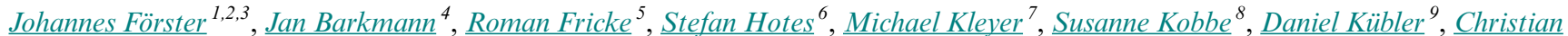

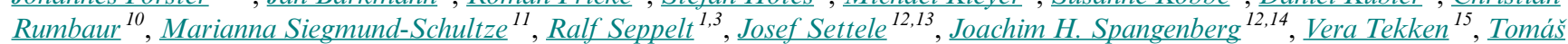 \\ Václavík $^{1,16}$ and Heidi Wittmer $^{2}$
}

\begin{abstract}
Assessments of ecosystem services (ES), that aim at informing decisions on land management, are increasing in number around the globe. Despite selected success stories, evidence for ES information being used in decision making is weak, partly because ES assessments are found to fall short in targeting information needs by decision makers. To improve their applicability in practice, we compared existing concepts of ES assessments with focus on informing land use decisions and identified opportunities for enhancing the relevance of ES assessments for decision making. In a process of codesign, building on experience of four projects in Brazil, China, Madagascar, and Vietnam, we developed a step-wise approach for better targeting ES assessments toward information needs in land use decisions. Our problem-oriented approach aims at (1) structuring ES information according to land use problems identified by stakeholders, (2) targeting context-specific ES information needs by decision makers, and (3) assessing relevant management options. We demonstrate how our approach contributes to making ES assessments more policy relevant and enhances the application of ES assessments as a tool for decision support.
\end{abstract}

Key Words: decision support; ecosystem services assessment; land use; problem-oriented;

\section{INTRODUCTION}

Assessments of ecosystem services (ES) are increasing in number (Seppelt et al. 2011, Abson et al. 2014), but it is questioned whether they actually generate knowledge that is relevant for decision makers (Honey-Rosés and Pendleton 2013, Laurans et al. 2013, Martinez-Harms et al. 2015). The majority of ES assessments tend to generate knowledge on ecological functions and economic values (Abson et al. 2014) with little consideration of the information demand by decision makers for addressing a particular land-use problem (Honey-Rosés and Pendleton 2013). For example, only 8 out of 340 cases of ES valuation published in scientific literature actually report how information on the value of ES is used in local decision making (Laurans et al. 2013). ES assessments have not yet proven to effectively change land management and policies in public and private sectors (Abson et al. 2014, Ruckelshaus et al. 2015).

Nonetheless, ES assessments can be an attractive tool for supporting decisions on land use because they can highlight benefits and trade-offs between different land-use options, ideally by integrating biophysical and socioeconomic methods (Daily et al. 2009, Fisher et al. 2009, TEEB 2010, Ruckelshaus et al. 2015). Therefore, ES assessments are increasingly used in decisionoriented processes, including environmental impact assessments (EIA; e.g., Pischke and Cashmore 2006) and land-use planning for biodiversity conservation (Goldman et al. 2008) and catchment management (e.g., Ruckelshaus et al. 2015). The ES concept is also popular in national and international policy processes, including national ecosystem assessments, the Aichi Biodiversity Targets of the United Nations Convention on Biological Diversity (CBD), the Work Plan of the Intergovernmental Platform on Biodiversity and Ecosystem Services (IPBES), and the Biodiversity Strategy of the European Union.

The term "ecosystem services" describes benefits that ecosystems - comprising species, genes, biotic and abiotic structures and processes - provide to human well-being (Millennium Ecosystem Assessment 2005, Fisher et al. 2009). Harnessing and managing ES often requires knowledge on the potential of ecosystems to provide ES and takes the investment of skills, labor, materials, and energy (Spangenberg et al. 2014a). The cultural and political context influences which ES are appropriated and how. Land use is then the result of this complex human-ecosystem interaction which is described as social-ecological system (SES; Ostrom 2007). Components or processes of ecosystems only become ES, if someone actively or passively benefits from them (Jax et al. 2013). Hence, the definition of ES involves subjective judgments of what is perceived as benefit, making ES a normative concept (Jax et al. 2013, Schröter et al. 2014). Using a broad interpretation,

${ }^{1}$ UFZ - Helmholtz Centre for Environmental Research, Department Computational Landscape Ecology, Leipzig, Germany, ${ }^{2}$ UFZ - Helmholtz Centre for Environmental Research, Department Environmental Politics, Leipzig, Germany, ${ }^{3}$ Institute of Geoscience \& Geography, Martin-LutherUniversity Halle-Wittenberg, Halle (Saale), Germany, ${ }^{4}$ Environmental and Resource Economics, Department of Agricultural Economics and Rural Development, Georg-August-Universität Göttingen, Göttingen, Germany, ${ }^{5}$ Faculty of Biology, Department of Animal Ecology, Philipps University of Marburg, Marburg, Germany, ${ }^{6}$ Department of Ecology, Animal Ecology, Philipps-Universität Marburg, Marburg, Germany, ${ }^{7}$ Landscape Ecology Group, Institute of Biology and Environmental Sciences, University of Oldenburg, Oldenburg, Germany, ${ }^{8}$ Department of Animal Ecology and Conservation, University of Hamburg, Biocentre Grindel, Hamburg, Germany, ${ }^{9}$ Institute for World Forestry, University of Hamburg, Hamburg, Germany, ${ }^{10}$ Hydrology and River Basin Management, Technische Universität München, München, Germany, ${ }^{11}$ Environmental Assessment and Planning Research Group, Technische Universität Berlin, Berlin, Germany, ${ }^{12}$ UFZ - Helmholtz Centre for Environmental Research, Department of Community Ecology, Animal Ecology and Social-Ecological Research, Halle, Germany, ${ }^{13} \mathrm{iDiv}$ - German Centre for Integrative Biodiversity Research, 04103 Leipzig, Germany, ${ }^{14}$ Sustainable Europe Research Institute SERI Germany, Cologne, Germany, ${ }^{15}$ Institute for Geography and Geology, Department of Sustainability Science and Applied Geography, Ernst Moritz Arndt University of Greifswald, Greifswald, Germany, ${ }^{16}$ Department of Ecology and Environmental Sciences, Palacký University Olomouc, Olomouc, Czech Republic 
in which ES benefits are based on multiple values, the ES concept can be valuable for decision support: it allows assessing human dependence on ecosystems through inter- and transdisciplinary research, integrating perspectives and values of different stakeholder groups, and guiding decisions on resource use (Reyers et al. 2010, Jax et al. 2013, Abson and Hanspach 2014, Schröter et al. 2014). A narrow interpretation, in which ES benefits are only based on monetary values, evokes criticism of the ES concept for being anthropocentric, fostering a utilitarian and economic perspective, with the risk of promoting commodification and exploitation of nature (Turnhout et al. 2013, Schröter et al. 2014). Because of this normative character, there is no standard interpretation and application of the ES concept, but it is clear that it requires transparency about its context, purpose, and definitions (Jax et al. 2013).

Since 1997 the number of scientific publications addressing ES has increased 27-fold, particularly in the natural-science literature (Abson et al. 2014). Biophysical characteristics of ES (e.g., Egoh et al. 2009), their cultural and social significance (e.g., Chan et al. 2012a, b), and economic value (e.g., Christie et al. 2012) are assessed and integrated into models (e.g., Nelson et al. 2009) and maps (e.g., Crossman et al. 2013) that describe interdependencies and trade-offs between land-use options. However, interdisciplinary ES assessments remain the exception with only $8.5 \%$ of ES studies being truly interdisciplinary (Abson et al. 2014).

Integrating a social-ecological system (SES) perspective into ES assessments, with land use being viewed as a system of interlinked natural and socio-political processes, offers a way of making such assessments more relevant to decision making (Spangenberg et al. 2014a). An SES perspective within ES assessments allows (i) the analysis of how human demand constitutes potential services (Spangenberg et al. 2014b), (ii) the identification of dependencies of ES users on ecosystems, and (iii) an understanding of tradeoffs among management options (Cowling et al. 2008, Seppelt et al. 2011, Carpenter et al. 2012).

Guidance exists on integrating an SES perspective into ES assessments (e.g., Reyers et al. 2013), accounting for cultural and social values (Chan et al. 2012a, b), using ES information in landscape planning and management (de Groot et al. 2010), and mainstreaming ES into policies and practice (Cowling et al. 2008, Daily et al. 2009). However, the attempt to account for all socialecological factors can make ES assessments a complex and resource-intense endeavor (e.g., Cowling et al. 2008, Chan et al. 2012a). Experience from practice shows that complex assessments are not necessarily more helpful for decision support (Ruckelshaus et al. 2015). Decision makers do not necessarily need an exhaustive understanding of the social-ecological system, but they need sufficient arguments to make a choice between landuse options. Therefore, designing problem-oriented ES assessments, which focus on the information demand by decision makers, can help make ES assessments more decision relevant (Honey-Rosés and Pendleton 2013).

To address this challenge, we compared existing frameworks for assessing ES in social-ecological systems. We identified prevailing gaps in these approaches and, based on the experience from four case studies in Brazil, China, Madagascar, and Vietnam, we codesigned and tested a problem-oriented ES assessment approach that prioritizes information demand by decision makers. We discuss how our approach contributes toward making ES assessments a more relevant tool for decision making. The case studies are part of the Sustainable Land Management (SLM) Program, funded by the German Federal Ministry for Education and Research (BMBF), with the objective of fostering transformations toward more sustainable land stewardship (Eppink et al. 2012).

\section{BUILDING ON FIELD EXPERIENCE}

Building on the experience of four place-based projects (Fig. 1) and comparing existing frameworks for ES assessments (Fig. 2), we collaboratively identified aspects that are critical for a problem-oriented ES assessment, using workshops and expert consultations. The four case studies use ES assessments to guide decisions on land use problems related to agriculture, water use, and ecosystem conservation at local to regional scales.

In Madagascar, the SuLaMa project identifies options for enhancing the resilience of local communities to shortages in food and water supply caused by climate variability, and for mitigating encroachment into a protected area (Fig. 3). The LEGATO project in Vietnam analyzes rice farming practices that enhance natural pest control, increase yields, and reduce the use of pesticides causing water pollution (Settele et al. 2013; Fig. 4). In the São Francisco River watershed in Brazil, the INNOVATE project analyzes ES to support the Watershed Committee in addressing conflicts over water use for irrigation agriculture, electricity generation from hydropower, and domestic water use, while maintaining sufficient water flow for river ecosystems (Siegmund-Schultze et al. 2015; Fig. 5). In the Tarim River Basin in China, the SuMaRiO project informs the regional government on benefits and trade-offs involved in water use for cotton irrigation and the conservation of riparian forests, considering threats related to desertification and climate change (Rumbaur et al. 2015; Fig 6).

We compare our approach with eight existing frameworks (Fig. 2) that focus on assessing ES within social-ecological systems (SES) with the aim of providing decision support (Cowling et al. 2008, Carpenter et al. 2009, Daily et al. 2009, Ostrom 2009, Chan et al. 2012a, TEEB 2012, Reyers et al. 2013, Martinez-Harms et al. 2015).

Only three out of eight frameworks provide explicit guidance for focusing ES assessments on decision relevant problems. The TEEB approach (TEEB 2012) and Chan et al. (2012a) require (1) agreement on the problem, to (2) prioritize ES according to their relevance to the problem and stakeholders, and to (3) identify information needs by decision makers. However, the TEEB approach (2012) remains vague in how to assess ES from a SES perspective and Chan et al. (2012a) target mainly cultural values. Martinez-Harms et al. (2015) emphasize the importance of a stakeholder-driven problem identification and specification of objectives at the beginning of the assessment process, but they note that only $8 \%$ of case studies actually use stakeholder consultations in this process. Nevertheless, they provide little guidance on how to target problems and objectives relevant to decision makers. The other five approaches acknowledge the need to account for concerns of stakeholders, but the gaps under "Scoping phase A" (Steps 1-3 on the left side of Fig. 2) depict the lack of explicit guidance on tailoring ES assessments to decision needs. 
Fig. 1. Case studies of the Sustainable Land Management Program (Eppink et al. 2012) for which the problemoriented approach was developed and exemplified. Videos summarizing each case study can be accessed at the Program's website (URL: http://modul-a.nachhaltiges-landmanagement.de/de/mediathek-modul-a/ videobeitraege/).

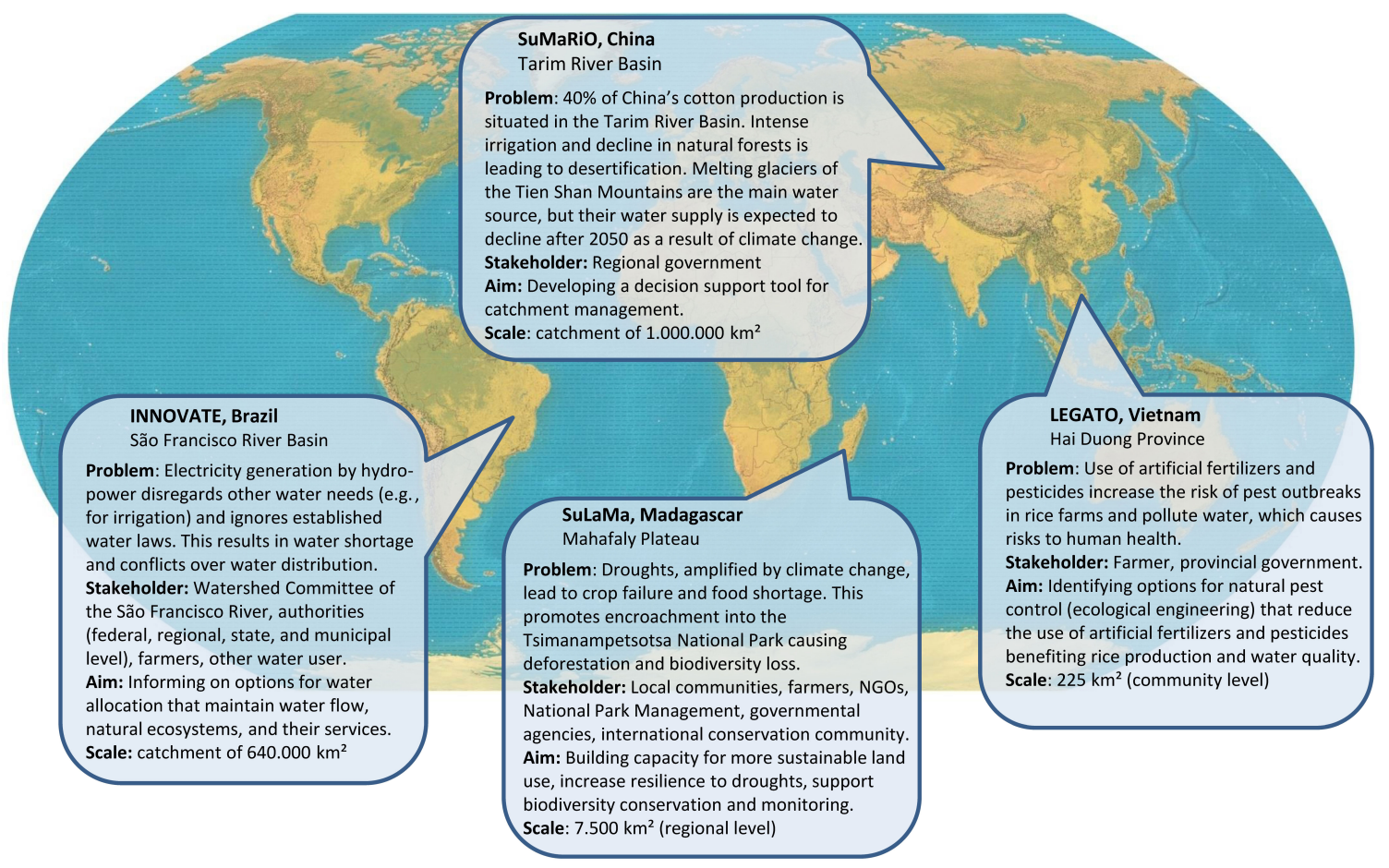

All approaches assume that developing an understanding of the social-ecological context and analyzing the flow of ES, their benefits, and trade-offs (Assessment phase B, Fig. 2) will generate information relevant to decision making (Implementation phase C, Fig. 2). This can be achieved, for example, through assessing the governance and resource system (Ostrom 2009), undertaking social and biophysical assessments (Cowling et al. 2008), analyzing the link between governance context and ES (Carpenter et al. 2009), and establishing social-ecological production functions (Reyers et al. 2013). However, trade-off analysis alone does not lead to changes in decision making (Daily et al. 2009). Focusing on the importance of ES information for decision making only after it has been generated involves the risk of missing decision relevant information. Furthermore, judging the relevance of information by scientific criteria can lead to advice that is lacking a policy perspective. It is recognized that, besides improving the science, a better integration of ES information in the development of policies and institutions is needed (Daily et al. 2009).

We propose closing these gaps by better tailoring ES assessments to problems at the very beginning of the assessment process and targeting specific information needs of decision makers. Building on the experience of the four case studies (Fig. 1), we developed a problem-oriented ES assessment approach to provide practical guidance for the assessment and synthesis of ES information with a focus on informing land-use decisions (Fig. 2). Our approach comprises a scoping phase (A), assessment phase (B), and implementation phase (C), and follows 5 steps: (Step 1) specify and agree with stakeholders on the problems to be addressed, (Step 2) identify ES beneficiaries and ES most relevant to decision making, (Step 3) define information needs of decision makers, (Step 4) assess ES flow within the SES context and impact of changes on ES benefits and trade-offs, and finally (Step 5) synthetize and integrate the generated information into processes of decision support. The approach is not intended to replace the existing frameworks, but to provide complementary guidance for designing and implementing ES assessments that are more relevant for decision making.

\section{APPLICATION}

In the following the problem-oriented approach of the SLM Program is exemplified along the four case studies (Figs. 3 to 6). The approach is not a static, prescriptive blueprint for a linear assessment process. Each ES assessment is a unique undertaking, adapted to a specific decision within a social-ecological system and point in time, producing context specific outcomes. Hence, designing and implementing ES assessments, aiming at more sustainable land-management options, requires transdisciplinary expertise that accommodates different types of knowledge and allows for responding to context specific information needs (Görg et al. 2014). Ideally, ES assessments are embedded in a sciencepractice partnership that enables cogeneration of knowledge, which is both user-inspired and user-relevant (Ntshotsho et al. 2015).

The presented approach is flexible in that the sequence of steps can be altered and the thematic and methodological focus can be 
Fig. 2. The problem-oriented approach for assessing ecosystem services (ES) of the Sustainable Land Management (SLM) Program (at top) compared with other approaches for assessing ES using a social-ecological systems (SES) perspective. Steps can be applied sequentially (arrows), interchangeably, and repetitively within iterative assessment procedures.

Problem-oriented ES assessment approach

Scoping phase (A): Determine demand for ES assessment.

Step 1:

Specify and

agree with

stakeholders

on problem

\section{Step 2: Identify}

ES beneficiaries

and select ES

most relevant

for decision

making information

needs of

decision

makers

\section{Assessment phase (B): Analyze ES within social-ecological context and impacts of} changes (e.g., in land use, policies, climate) on ES flow, benefits, and trade-offs.

Step 3: Define
Step 4a: Assess

current

management

and alternative

options

\section{Step 4b: Assess}

role of

biodiversity and

ecosystem

processes for provision of ES
Step 4c: Assess Step 4d:

how changes in

$4 a$ and $4 b$

benefits,

impact ES flow trade-offs

beyond land

use and ES
Implementation phase (C).

Step 5:

Synthetize and

integrate

information for

decision support
Making decisions for managing ES (Martinez-Harms et al. 2015)

\begin{tabular}{|l|l|l|l|}
\begin{tabular}{|l|l|l|} 
Specify \\
objectives \& \\
performance \\
measures
\end{tabular} & $\begin{array}{l}\text { Alternative } \\
\text { actions }\end{array}$ & $\begin{array}{l}\text { Performance } \\
\text { measures }\end{array}$ & $\begin{array}{l}\text { Trade-offs and } \\
\text { consequences }\end{array}$ \\
\cline { 2 - 4 } & Develop understanding of SES context & \multicolumn{2}{|l}{} \\
\hline
\end{tabular}

Getting the measure of ES: a social-ecological approach (Reyers et al. 2013)

\begin{tabular}{|l|l|l|l|}
$\begin{array}{l}\text { Governance, } \\
\text { management }\end{array}$ & $\begin{array}{l}\text { ES production } \\
\text { functions }\end{array}$ & ES bundles & $\begin{array}{l}\text { Benefit flow, } \\
\text { beneficiaries, } \\
\text { human well-being }\end{array}$ \\
\cline { 2 - 3 }
\end{tabular}

TEEB six-step approach for considering the benefits of nature (TEEB 2012)

\begin{tabular}{|l|l|l|l|}
\hline $\begin{array}{l}\text { Agree on } \\
\text { problem }\end{array}$ & ES priorities & $\begin{array}{l}\text { Information } \\
\text { needs }\end{array}$ & $\begin{array}{l}\text { Assess policy } \\
\text { options }\end{array}$ \\
\hline
\end{tabular}

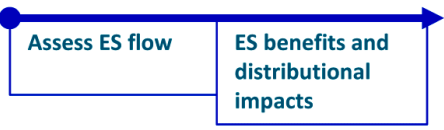

Where are cultural and social in ES? A framework for constructive engagement (Chan et al. 2012)

Determine decision context context

Determine and prioritize benefits, ES and values

ES in decision making: time to deliver (Daily et al. 2009)

\begin{tabular}{|l|l} 
Stakeholders define alternative & ES production functions
\end{tabular}

scenarios

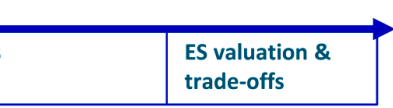

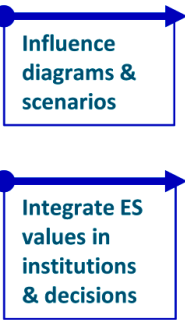

Science for managing ES: Beyond the Millennium Ecosystem Assessment (Carpenter et al. 2009)

\begin{tabular}{|c|c|c|c|}
\hline $\begin{array}{c}\text { Understand coupled } \\
\text { social-ecological systems }\end{array}$ & $\begin{array}{c}\text { Feedback between ES and human } \\
\text { well-being (HWB); ES tradeoffs }\end{array}$ & $\begin{array}{c}\text { Link to other } \\
\text { HWB factors }\end{array}$ & $\begin{array}{l}\text { Inform policies } \\
\text { \& governance }\end{array}$ \\
\hline
\end{tabular}

A general framework for analyzing sustainability of social-ecological systems (Ostrom 2009)

\begin{tabular}{|l|l|l|l|l|l|}
\hline $\begin{array}{l}\text { Governance } \\
\text { system (GS) }\end{array}$ & $\begin{array}{l}\text { Resource system } \\
\text { (RS) }\end{array}$ & $\begin{array}{l}\text { Resource units } \\
\text { (RU) }\end{array}$ & Users (U) & $\begin{array}{l}\text { Externalities } \\
\text { to other SES }\end{array}$ & $\begin{array}{l}\text { Interactions } \\
\text { \& outcomes }\end{array}$ \\
\hline \multicolumn{4}{|c|}{ Social, economic, political setting } & \\
\hline
\end{tabular}

An operational model for mainstreaming ES for implementation (Cowling et al. 2008)

\begin{tabular}{|l|l|l|}
\hline $\begin{array}{l}\text { Social assessment: stakeholder } \\
\text { needs, values, norms, practices }\end{array}$ & Biophysical assessment & ES valuation assessment \\
\hline \multicolumn{3}{|c|}{ Assessment phase } \\
\hline
\end{tabular}


Fig. 3. Problem-oriented approach for assessing ecosystem services (ES): the case of the SuLaMa project on subsistence farming in Madagascar.

\begin{tabular}{|c|c|c|c|c|c|c|c|c|}
\hline \multicolumn{3}{|c|}{$\begin{array}{l}\text { Scoping phase (A): Determine the demand for the ES } \\
\text { assessment. }\end{array}$} & \multicolumn{5}{|c|}{$\begin{array}{l}\text { Assessment phase (B): Analyze ES within social-ecological context and impacts of changes (e.g., in land } \\
\text { use, policies, climate) on ES flow, benefits, and trade-offs. }\end{array}$} & \multirow{2}{*}{$\begin{array}{l}\text { Implementation } \\
\text { phase (C). } \\
\text { Step 5: Synthetize } \\
\text { and integrate } \\
\text { information for } \\
\text { decision support }\end{array}$} \\
\hline $\begin{array}{l}\text { Step 1: Specify and } \\
\text { agree with } \\
\text { stakeholders on } \\
\text { problem and relevant } \\
\text { research question }\end{array}$ & $\begin{array}{l}\text { Step 2: Identify ES } \\
\text { beneficiaries and } \\
\text { select ES most } \\
\text { relevant for } \\
\text { decision making }\end{array}$ & $\begin{array}{l}\text { Step 3: Define } \\
\text { information } \\
\text { needs of decision } \\
\text { makers }\end{array}$ & $\begin{array}{l}\text { Step 4a: Assess } \\
\text { current management } \\
\text { and alternative } \\
\text { options }\end{array}$ & $\begin{array}{l}\text { Step 4b: Assess } \\
\text { role of biodiversity } \\
\text { and ecosystem } \\
\text { processes for } \\
\text { provision of ES }\end{array}$ & $\begin{array}{l}\text { Step 4c: Assess flow of ES } \\
\text { and how changes in } 4 \mathrm{a} \text { and } \\
4 \mathrm{~b} \text { impact ES flow }\end{array}$ & $\begin{array}{l}\text { Step 4d: Determine ES } \\
\text { benefits, values, and } \\
\text { ES trade-offs }\end{array}$ & $\begin{array}{l}\text { Step 4e: } \\
\text { Account for } \\
\text { impacts } \\
\text { beyond land } \\
\text { use and ES }\end{array}$ & \\
\hline $\begin{array}{l}\text { Communities suffer } \\
\text { from food insecurity } \\
\text { and few or no } \\
\text { alternative income } \\
\text { sources. } \\
\text { Managers of the } \\
\text { Tsimanampetsotsa } \\
\text { National Park (NPM) } \\
\text { identified } \\
\text { deforestation and } \\
\text { forest degradation } \\
\text { mainly caused by } \\
\text { farmers as causes for } \\
\text { biodiversity loss. } \\
\text { Conflicts between } \\
\text { farmers and } \\
\text { biodiversity } \\
\text { conservation in } \\
\text { National Park. } \\
\text { Drivers causing the } \\
\text { problem include: } \\
\text { poverty, population } \\
\text { growth, crop failure } \\
\text { due to weather events } \\
\text { including droughts, } \\
\text { soil degradation, pests } \\
\text { damaging crops, poor } \\
\text { infrastructure } \\
\text { (storage, market } \\
\text { access). }\end{array}$ & $\begin{array}{l}\text { Farmers benefit } \\
\text { from: } \\
\text { Provision of food } \\
\text { from cultivated } \\
\text { crops, livestock, } \\
\text { wild alimentary } \\
\text { plants, and wildlife, } \\
\text { medicinal plants, } \\
\text { fodder for livestock, } \\
\text { fuelwood and } \\
\text { timber from forests. } \\
\text { Regulation of soil } \\
\text { fertility, pest } \\
\text { control, water } \\
\text { availability. } \\
\text { Cultural values } \\
\text { including livestock } \\
\text { as indicator for } \\
\text { wealth and status, } \\
\text { use of wild plants } \\
\text { for ritual purposes. } \\
\text { National Park } \\
\text { Management } \\
\text { benefits from } \\
\text { maintaining habitat } \\
\text { for biodiversity } \\
\text { conservation. }\end{array}$ & $\begin{array}{l}\text { Information is } \\
\text { needed on } \\
\text { options for } \\
\text { diversifying } \\
\text { income strategies } \\
\text { of farmers and for } \\
\text { building resilience } \\
\text { to environmental } \\
\text { shocks (droughts) } \\
\text { and income loss. } \\
\text { How can the } \\
\text { already existing } \\
\text { coping strategies } \\
\text { be enhanced? } \\
\text { Information is } \\
\text { needed on use of } \\
\text { drought resistant } \\
\text { crops, enhancing } \\
\text { soil fertility and } \\
\text { pest control, and } \\
\text { livestock } \\
\text { management, } \\
\text { sustainable use of } \\
\text { wild plants and } \\
\text { wildlife. } \\
\text { National Park } \\
\text { Management } \\
\text { requires better } \\
\text { monitoring of } \\
\text { biodiversity and } \\
\text { habitat quality. }\end{array}$ & $\begin{array}{l}\text { Current subsistence } \\
\text { farming practices } \\
\text { already include } \\
\text { diversified strategies } \\
\text { for crop and livestock } \\
\text { production in order to } \\
\text { reduce risks related to } \\
\text { droughts and pests. } \\
\text { Option 1: Explore local } \\
\text { crop varieties that are } \\
\text { more resistant to } \\
\text { droughts and pests } \\
\text { (e.g., bird resistant } \\
\text { millet). } \\
\text { Options 2: Test } \\
\text { alternative sources of } \\
\text { fodder for livestock } \\
\text { during droughts in } \\
\text { order to avoid } \\
\text { encroachment in } \\
\text { protected area. } \\
\text { Option 3: Promote } \\
\text { home gardens for } \\
\text { planting vegetables } \\
\text { for domestic } \\
\text { consumption and sale } \\
\text { on markets. } \\
\text { Option 4: Assess role } \\
\text { of wild plants and } \\
\text { wildlife for income } \\
\text { diversification. }\end{array}$ & $\begin{array}{l}\text { Option 1: Analyze } \\
\text { resistance of } \\
\text { different crop } \\
\text { varieties to } \\
\text { droughts and pests } \\
\text { and test options for } \\
\text { enhancing soil } \\
\text { fertility. } \\
\text { Option 2: Analyze } \\
\text { productivity of } \\
\text { Samata, a plant } \\
\text { potentially serving } \\
\text { as alternative } \\
\text { fodder for livestock. } \\
\text { Option 3: Analyze } \\
\text { productivity of } \\
\text { home gardens. } \\
\text { Option 4: Assess } \\
\text { wild plants and } \\
\text { animals used by } \\
\text { households. } \\
\text { Monitoring of } \\
\text { National Park: } \\
\text { analyze species } \\
\text { abundance, } \\
\text { deforestation, and } \\
\text { forest degradation } \\
\text { rates as indicators } \\
\text { for habitat quality. }\end{array}$ & $\begin{array}{l}\text { Option 1: Local corn is fast } \\
\text { growing but little drought } \\
\text { resistant. Local manioc is } \\
\text { resistant against pests, but } \\
\text { achieves lower prize on } \\
\text { market as it is less tasty. } \\
\text { Resistance of millet to } \\
\text { birds needs further testing. } \\
\text { Option 2: Suitability of } \\
\text { Samata as fodder is tested } \\
\text { (biomass and nutrient } \\
\text { content). Water need for } \\
\text { Samata could conflict with } \\
\text { water need for food crops. } \\
\text { Option 3: Home gardens } \\
\text { have positive influence on } \\
\text { food production for } \\
\text { personal consumption and } \\
\text { for sale on market. } \\
\text { Option 4: Wild plants and } \\
\text { wildlife provide food in } \\
\text { periods of droughts. } \\
\text { Medicinal plants are } \\
\text { important for health care. } \\
\text { Trade-offs to be assessed: } \\
\text { Competition among } \\
\text { farmers for water, land, and } \\
\text { labor. Changes in spatial } \\
\text { patterns of land use and } \\
\text { impacts on encroachment } \\
\text { into national park. }\end{array}$ & $\begin{array}{l}\text { Option 1: Farmers } \\
\text { benefit from crop } \\
\text { diversification. It can } \\
\text { improve food security, } \\
\text { income, and increase } \\
\text { resilience to droughts. } \\
\text { However, best use of } \\
\text { local varieties is still } \\
\text { unclear. } \\
\text { Option 2: Fodder } \\
\text { cultivation (Samata) } \\
\text { has potential to } \\
\text { support livestock } \\
\text { production. The } \\
\text { potential scale of this } \\
\text { practice is unclear yet. } \\
\text { Option 3: Home } \\
\text { gardens enhance food } \\
\text { security and income } \\
\text { for farmers and in } \\
\text { particular women. } \\
\text { Option 4: Wild plants } \\
\text { and animals } \\
\text { contribute to food } \\
\text { security and health. } \\
\text { The extent to which } \\
\text { these options can } \\
\text { reduce encroachment } \\
\text { and deforestation in } \\
\text { the national park is } \\
\text { still being assessed. }\end{array}$ & $\begin{array}{l}\text { Cultural } \\
\text { impacts: } \\
\text { change in } \\
\text { livestock } \\
\text { production } \\
\text { can lead to } \\
\text { social } \\
\text { changes, as } \\
\text { the number of } \\
\text { livestock } \\
\text { determines } \\
\text { the social } \\
\text { status. } \\
\text { Changes in } \\
\text { livestock } \\
\text { distribution } \\
\text { can impact } \\
\text { behavior of } \\
\text { cattle thieves. } \\
\text { Tourism } \\
\text { sector can } \\
\text { increase in } \\
\text { region with } \\
\text { potential } \\
\text { impacts on } \\
\text { income } \\
\text { generation } \\
\text { and cultural } \\
\text { values. }\end{array}$ & $\begin{array}{l}\text { Recommendations to } \\
\text { local organizations } \\
\text { and decision makers } \\
\text { include: } \\
\text { Diversification of crop } \\
\text { and fodder } \\
\text { production (option } 1 \\
\text { and 2) can be a viable } \\
\text { option for enhancing } \\
\text { resilience of local } \\
\text { communities, since } \\
\text { diversification is } \\
\text { already part of } \\
\text { traditional farming } \\
\text { practices. However, } \\
\text { the effect on } \\
\text { increasing income is } \\
\text { unclear yet. Water } \\
\text { remains to be a } \\
\text { limiting factor. } \\
\text { Farmers and in } \\
\text { particular women } \\
\text { benefit from home } \\
\text { gardens as a source of } \\
\text { food and income. } \\
\text { Home gardens } \\
\text { (option } 3 \text { ) should be } \\
\text { promoted. } \\
\\
\text { The effect of options } \\
1-4 \text { on reducing } \\
\text { encroachment into } \\
\text { the national park is } \\
\text { still unclear. }\end{array}$ \\
\hline
\end{tabular}

adapted to stakeholder needs. Applied in an iterative process, information generated in one step can inform previous and consecutive steps in feedback loops. The normative character of the ES concept helps to take into account different cultural and socioeconomic contexts and decision-making processes (Schröter et al. 2014) and to integrate multiple types of knowledge, e.g., combining traditional and scientific information. Integrative tools, which combine methods of natural and social science and synthesize qualitative and quantitative information, e.g., multicriteria analysis, tools for spatial analysis, and social-ecological models, are increasingly applied for ES assessments (e.g., Bagstad et al. 2013).

\section{Scoping phase (A)}

\section{Step 1: Specify and agree with stakeholders on problem}

Land-use related problems, drivers, and impacts are identified in step 1 through consultations of experts and stakeholders, review of literature, and available data (Table 1). Because stakeholders are not a homogenous group, e.g., politicians and farmers are both decision makers, consensus on often multilayered problems cannot be taken for granted. For example, in the case of competition for scarce resources, ES information can empower one party over others, leading to inequalities and potential conflicts. Thus, analyzing the distribution of benefits and disbenefits and the impacts on power relations is an important starting point for determining the focus and scales of the assessment.
For example, stakeholder interviews and constellation analysis (e.g., Bruns et al. 2011) helped INNOVATE in Brazil and SuMaRiO in China to identify large-scale water allocation issues at a catchment scale (area of $640.000 \mathrm{~km}^{2}$ and 1 million $\mathrm{km}^{2}$ respectively; step 1 in Figs. 5 and 6). In these catchments, water use involves trade-offs between irrigation, hydropower production, and maintaining minimum ecological flow for sustaining natural ecosystems that provide habitat for biodiversity and mitigate desertification (e.g., Siew et al. 2014). In contrast, the projects SuLaMa in Madagascar and LEGATO in Vietnam target farmers who make decisions on crop and livestock production ranging from a few hectares up to regional scales within mosaic landscapes (areas of $7500 \mathrm{~km}^{2}$ and $225 \mathrm{~km}^{2}$ ). SuLaMa and LEGATO aim at enhancing resilience of agricultural production against droughts and pest outbreaks to increase food security and household income, while ensuring biodiversity conservation (step 1 in Figs. 3 and 4).

To ensure a focus on "real-life" problems, LEGATO followed an approach of codesign and coproduction. Using stakeholder dialogues, relevant partners including local decision makers, farmers, researchers, and research institutions were consulted to identify research needs and elucidate synergies in capacities, knowledge, and skills. This process also ensured political acceptance and support of the project by all partners, taking into account institutional settings, involving different levels of local and regional governance, and respecting power structures. 
Table 1. Examples of questions, actions, and indicators for determining the demand for the ecosystem services (ES) assessment (Scoping phase A).

Scoping phase (A): Determine the demand for the ES assessment
Questions
Actions

Questions Actions

Step 1: Specify and agree with stakeholders on problem Who are stakeholder groups and which problems are they concerned about?

Consulting stakeholders, decision makers, and experts using participatory approaches, e.g., interviews, group consultations, surveys,

Are these problems caused by or linked to land and multicriteria analysis (e.g., Saarikoski et use? al. $2013 a$ ).

Which socioeconomic or ecological drivers influence the problem?

What are the spatiotemporal scales of the problem and who is affected?

Exploring available data and statistics on environmental and socioeconomic variables.

Literature analysis

Are problems related to policies?

Step 2: Identify ES beneficiaries and select ES most relevant for decision making

Which stakeholder groups or experts should be Consulting stakeholders, decision makers,

involved in ES identification and prioritization? and experts on preferences for certain ES

Which ecosystems and ES are related to the problem? Which ES benefits are of particular importance to stakeholders? Are they part of a coproduced ES bundle?

Who suffers from disbenefits / trade-offs? Which distributional challenges emerge? different knowledge types, values, and
Indicators (qualitative \& quantitative)

Issues addressed in meetings and interviews with stakeholder groups, decision makers, and experts;

Status and trends of environmental variables, e.g., water quality, habitat size, yield, climate, etc.;

Status and trends in socioeconomic variables, e.g., income, health, access to resources, etc.;

Size of affected area and population. bundles and related trade-offs (e.g., Martín-

$$
\text { López et al. 2014). }
$$

Allowing flexibility for accommodating convictions. Adapting terminology and classification to stakeholder needs, while ensuring compatibility with common ES classification systems (e.g., Fisher et al. 2009, Haines-Young and Potschin 2012).
Types of benefits derived from ES, e.g., consumption, income, etc., types of disbenefits;

Stakeholder groups and number of people benefiting from ES (beneficiaries and ES demand) or suffering disbenefits;

Location and area of ecosystems that provide direct and indirect benefits to stakeholder groups (ES supply); Location and area of region that is benefiting from ES provision (ES demand);

Importance of ES benefits for wellbeing of stakeholders and related disbenefits.

Stakeholder groups involved in decision making and their respective interests;

Stakeholder groups not involved and reasons for exclusion;

Awareness of decision makers of identified problem and ES;

Analyzing potential knowledge gaps, conflicting interests of stakeholder groups, and beneficiaries of ES information, e.g., empowerment of certain groups.

If so, is there a window of opportunity for using ES information in current or upcoming land-use decisions?

Providing lessons learned in comparable decision contexts. For example, Garrick et al. (2009) compare how ES information On what criteria are land-use decisions based so influenced decisions on water management far (economic benefits, traditional rules, etc.) and by which group of decision makers? Does a link to ES exist (irrespective of the terminology used)?

When in the decision process is what type of information needed by whom and for which purpose? in two basins in the USA and Australia.

Exploring historical data on information used in decision making. For example Wilkinson et al. (2013) compare historical changes in the use of ES information for urban planning in Melbourne and Stockholm.
Decisions or decision processes mentioned by decision makers;

Social-ecological variables mentioned by decision makers to be of relevance;

Timing of decision processes;

Problems, decisions, and variables identified by the research team but not mentioned by decision makers, or only by subgroups.

Which level of detail is required?

What are knowledge gaps related to the identified problems and ES? 
Fig. 4. Problem-oriented approach for assessing ecosystem services (ES): the case of the LEGATO project on rice farming in Vietnam (Settele et al. 2013).

\begin{tabular}{|c|c|c|c|c|c|c|c|c|}
\hline \multicolumn{3}{|c|}{$\begin{array}{l}\text { Scoping phase (A): Determine the demand for the ES } \\
\text { assessment. }\end{array}$} & \multicolumn{5}{|c|}{$\begin{array}{l}\text { Assessment phase (B): Analyze ES within social-ecological context and impacts of changes (e.g., in land } \\
\text { use, policies, climate) on ES flow, benefits, and trade-offs. }\end{array}$} & \multirow{2}{*}{$\begin{array}{l}\text { Implementation } \\
\text { phase (C). } \\
\text { Step 5: Synthetize } \\
\text { and integrate } \\
\text { information for } \\
\text { decision support }\end{array}$} \\
\hline $\begin{array}{l}\text { Step 1: Specify and } \\
\text { agree with } \\
\text { stakeholders on } \\
\text { problem and relevant } \\
\text { research question }\end{array}$ & $\begin{array}{l}\text { Step 2: Identify ES } \\
\text { beneficiaries and } \\
\text { select ES most } \\
\text { relevant for } \\
\text { decision making }\end{array}$ & $\begin{array}{l}\text { Step 3: Define } \\
\text { information } \\
\text { needs of decision } \\
\text { makers }\end{array}$ & $\begin{array}{l}\text { Step 4a: Assess current } \\
\text { management and } \\
\text { alternative options }\end{array}$ & $\begin{array}{l}\text { Step 4b: Assess } \\
\text { role of biodiversity } \\
\text { and ecosystem } \\
\text { processes for } \\
\text { provision of ES }\end{array}$ & $\begin{array}{l}\text { Step 4c: Assess flow of } \\
\text { ES and how changes in } \\
4 a \text { and } 4 b \text { impact ES } \\
\text { flow }\end{array}$ & $\begin{array}{l}\text { Step 4d: Determine ES } \\
\text { benefits, values, and } \\
\text { ES trade-offs }\end{array}$ & $\begin{array}{l}\text { Step 4e: } \\
\text { Account for } \\
\text { impacts } \\
\text { beyond land } \\
\text { use and ES }\end{array}$ & \\
\hline $\begin{array}{l}\text { Rice farmers suffer } \\
\text { from water pollution } \\
\text { caused by the use of } \\
\text { pesticides and } \\
\text { frequent incidences of } \\
\text { rice pests. Loss of land } \\
\text { due to conversion for } \\
\text { industry, settlement, } \\
\text { and infrastructure. } \\
\text { Poverty: Farmers have } \\
\text { few or no alternative } \\
\text { income sources. } \\
\text { Production costs of } \\
\text { rice farming are } \\
\text { increasing due to use } \\
\text { of artificial fertilizers } \\
\text { and pesticides. } \\
\text { Development plans of } \\
\text { provincial government } \\
\text { focus on promoting } \\
\text { tourism and industry } \\
\text { with little attention to } \\
\text { sustainable farming } \\
\text { practices. } \\
\text { Drivers: poverty, } \\
\text { water scarcity and } \\
\text { pollution, pest } \\
\text { infestations of rice } \\
\text { farms, population } \\
\text { growth, expansion of } \\
\text { urban, and industrial } \\
\text { areas. }\end{array}$ & $\begin{array}{l}\text { Rice farmers } \\
\text { benefit from: } \\
\text { Provisioning ES: rice } \\
\text { yield and biomass; } \\
\text { Regulating ES: soil } \\
\text { fertility, pest } \\
\text { control, and } \\
\text { pollination; } \\
\text { Cultural ES: } \\
\text { heritage, identity, } \\
\text { aesthetics, } \\
\text { education, and } \\
\text { tourism. } \\
\text { Tourists benefit } \\
\text { from heritage of } \\
\text { historical buildings } \\
\text { and landscape, } \\
\text { religious purpose of } \\
\text { temples, pilgrimage; } \\
\text { leisure from } \\
\text { recreational ES. } \\
\text { Government has } \\
\text { leading role in } \\
\text { modernizing rice } \\
\text { production and } \\
\text { managing transition } \\
\text { from an agricultural } \\
\text { society to urban, } \\
\text { industrial society. }\end{array}$ & $\begin{array}{l}\text { Farmers require } \\
\text { knowledge on } \\
\text { alternative } \\
\text { farming practices } \\
\text { that can: } \\
\text { - reduce the use of } \\
\text { artificial pesticides } \\
\text { and fertilizers; } \\
\text { - reduce water } \\
\text { pollution; } \\
\text { - promote natural } \\
\text { pest control; } \\
\text { - enhance soil } \\
\text { nutrients; } \\
\text { - reduce post- } \\
\text { harvest losses } \\
\text { (e.g., dryers, safe } \\
\text { storage facilities). } \\
\text { - increase farm- } \\
\text { gate selling price } \\
\text { (access to new } \\
\text { markets). } \\
\\
\text { Can natural pest } \\
\text { control replace } \\
\text { artificial } \\
\text { pesticides and } \\
\text { fertilizers while } \\
\text { maintaining yields } \\
\text { and income? } \\
\text { Identify } \\
\text { alternative } \\
\text { income sources, } \\
\text { e.g., from tourism. }\end{array}$ & $\begin{array}{l}\text { Rice farming: Assess } \\
\text { role of already existing } \\
\text { traditional farming } \\
\text { practices for natural } \\
\text { pest control, enhancing } \\
\text { crop yields, and } \\
\text { promoting soil nutrient } \\
\text { cycles. } \\
\text { Test and apply methods } \\
\text { of ecological } \\
\text { engineering that } \\
\text { promote natural pest } \\
\text { control. } \\
\text { Explore options for } \\
\text { diversifying income: } \\
\text { Producing and } \\
\text { marketing organic rice } \\
\text { products; } \\
\text { Engaging in tourism- } \\
\text { based income } \\
\text { generation; } \\
\text { Developing tourism } \\
\text { infrastructure to attract } \\
\text { international tourists to } \\
\text { cultural heritage and } \\
\text { landscape amenities. } \\
\text { Consider role of societal } \\
\text { drivers in particular the } \\
\text { potential impacts of } \\
\text { urbanization and } \\
\text { industrialization on } \\
\text { future development of } \\
\text { rice farming. }\end{array}$ & $\begin{array}{l}\text { Assessment of } \\
\text { natural pest } \\
\text { control: } \\
\text { Analyze species } \\
\text { diversity of insects } \\
\text { in rice fields for } \\
\text { assessing the } \\
\text { influence of } \\
\text { different farming } \\
\text { practices on the } \\
\text { abundance of } \\
\text { natural predators } \\
\text { that control pests } \\
\text { (e.g., damsel- and } \\
\text { dragonflies). } \\
\text { Pollinators: Assess } \\
\text { abundance of } \\
\text { pollinators in order } \\
\text { to assess influence } \\
\text { of biodiversity on } \\
\text { productivity of } \\
\text { crops other than } \\
\text { rice (e.g., fruits). } \\
\text { Soil nutrients: } \\
\text { Conduct field } \\
\text { experiments on } \\
\text { decomposition and } \\
\text { soil nutrient cycling. } \\
\text { Tourism: Assess link } \\
\text { between landscape } \\
\text { structure and } \\
\text { aesthetics value and } \\
\text { recreation. }\end{array}$ & $\begin{array}{l}\text { Assess how farming } \\
\text { practices: } \\
\text { enhance yield of rice, } \\
\text { vegetables, fruits, nuts, } \\
\text { spices, meat, pork, and } \\
\text { chicken; } \\
\text { influence regulating ES } \\
\text { such as natural pest } \\
\text { control, pollination, and } \\
\text { functional diversity; } \\
\text { impact water quality } \\
\text { with relevance for } \\
\text { domestic water use and } \\
\text { health. } \\
\text { Applying ecological } \\
\text { engineering can } \\
\text { potentially enhance } \\
\text { natural pest control, } \\
\text { enhance yields of farms, } \\
\text { reduce need for artificial } \\
\text { pesticides, and reduce } \\
\text { water pollution. } \\
\text { Influence of land use on } \\
\text { cultural services: } \\
\text { Traditional land-use } \\
\text { practices are linked to } \\
\text { cultural identity, social } \\
\text { structures, and rituals } \\
\text { connected to nature. } \\
\text { Historical-cultural } \\
\text { identity is supported by } \\
\text { old temples and other } \\
\text { historical sites. }\end{array}$ & $\begin{array}{l}\text { Beneficiaries of ES: } \\
\text { Rice farmers, millers, } \\
\text { traders, consumers, } \\
\text { employees in tourism, } \\
\text { city dweller seeking } \\
\text { recreation, } \\
\text { government (taxes). } \\
\text { Potential benefits of } \\
\text { changing farming } \\
\text { practices to ecological } \\
\text { engineering: more } \\
\text { stable rice yields, } \\
\text { higher market value of } \\
\text { organic rice, } \\
\text { cost savings and } \\
\text { health benefits from } \\
\text { reduced use of } \\
\text { pesticides, cleaner } \\
\text { water, enhanced } \\
\text { reputation of farmers } \\
\text { from producing clean } \\
\text { and healthy products, } \\
\text { providing perspective } \\
\text { to young farmers, } \\
\text { stronger cultural } \\
\text { identity and aesthetics } \\
\text { value due to more } \\
\text { diverse landscape, } \\
\text { benefiting tourism } \\
\text { (jobs, income). } \\
\text { Trade-off: farming } \\
\text { competes with } \\
\text { industry offering jobs } \\
\text { and income. }\end{array}$ & $\begin{array}{l}\text { Training in } \\
\text { ecological } \\
\text { engineering } \\
\text { can provide } \\
\text { farmers with } \\
\text { capacity, } \\
\text { awareness } \\
\text { and skills that } \\
\text { are also of } \\
\text { relevance in } \\
\text { other sectors } \\
\text { and enhance } \\
\text { diversification } \\
\text { of income } \\
\text { strategies. } \\
\text { Reduction of } \\
\text { dependency } \\
\text { on agro- } \\
\text { chemicals } \\
\text { allows more } \\
\text { self- } \\
\text { determined } \\
\text { farming with } \\
\text { potential to } \\
\text { reduce costs. } \\
\text { Socio- } \\
\text { economic } \\
\text { impacts of } \\
\text { industrial and } \\
\text { urban } \\
\text { development } \\
\text { are significant } \\
\text { but are not } \\
\text { assessed. }\end{array}$ & $\begin{array}{l}\text { Revise } \\
\text { recommendations by } \\
\text { regional government } \\
\text { on rice farming. } \\
\text { Revitalize traditional } \\
\text { farming practices that } \\
\text { require less artificial } \\
\text { fertilizers and } \\
\text { pesticides, as this } \\
\text { benefits pest control, } \\
\text { water quality and } \\
\text { income. } \\
\text { Enhance knowledge } \\
\text { on role of biodiversity } \\
\text { for pest control. } \\
\text { Provide training on } \\
\text { ecological engineering } \\
\text { in particular for young } \\
\text { generation of farmers } \\
\text { and decision makers. } \\
\text { Build capacity for } \\
\text { assessing trade-offs } \\
\text { between different } \\
\text { land-use options. } \\
\text { Guarantee long-term } \\
\text { lease. Enlarge fields. } \\
\text { Promote marketing } \\
\text { of organic farm } \\
\text { products. } \\
\text { Communicate results } \\
\text { to intergovernmental } \\
\text { organizations, e.g., } \\
\text { Asian Development } \\
\text { Bank (ADB). }\end{array}$ \\
\hline
\end{tabular}

Step 2: Identify ES beneficiaries and select ES most relevant for decision making

Step 2 covers prioritization of ES according to their relevance to the identified problem, affected stakeholders, and the decision to be informed (Chan et al. 2012a, TEEB 2012; Table 1). Special attention should be given to diverging interests and the distribution of benefits and costs. To do so, it is critical to integrate a range of knowledge sources of multiple stakeholder groups, including farmers, indigenous peoples, decision makers in public administration and private businesses, but also researchers and experts with particular knowledge of the system. The focus on prioritized ES has the advantage of targeting ES assessments toward specific land-use problems, taking into account available capacities and resources. However, because many ES are coproduced in bundles with benefits and costs to different stakeholders, the analysis must not be limited to single ES, monetary benefits, or selected stakeholders, which would ignore ecological context and distributional effects.

For example in Vietnam, the involvement of different farmer groups and generations was needed to realize that traditional rice farming practices maintain species compositions that provide natural pest control, while artificial pesticides together with fertilizers cause water pollution and health issues. Thus, better understanding of farming practices that enhance natural pest control and reduce use of pesticides was identified to be the focus of the LEGATO project (step 2, Fig. 4). However, institutional issues can also play a role in prioritizing ES. Because of the relevance of rice farming for local and national economy, LEGATO sought contact to provincial governors, heads of administration, and national senators. Consequently, both direct and indirect beneficiaries of rice production were included among stakeholders. This helped reveal ES related to rice production, identify disciplinary overlaps, and fill gaps in the choice of decision makers to be involved.

There is the risk of overlooking ES or stakeholder groups that have not been prioritized in the first place, but are found to be important later in the assessment process. For example, in the INNOVATE project in Brazil, the relatively new and not yet generally recognized Watershed Committee was identified as an important stakeholder group after a series of expert consultations (step 1 and 3, Fig. 5). Furthermore, unexpected events can impact project priorities. During the course of the INNOVATE project a particularly strong drought triggered societal concerns over water quantity. Hence, ES related to water quantity increased in importance.

This decision-focused approach differs from the recommendation by Reyers et al. (2013), who suggest to assess the entire bundle of ES to address the full range of consequences and trade-offs involved in decision making. Although assessing the entire bundle of ES is certainly important for a complete trade-off analysis, it 
Fig. 5. Problem-oriented approach for assessing ecosystem services (ES): the case of the INNOVATE project in the River São Francisco Watershed in Brazil.

\begin{tabular}{|c|c|c|c|c|c|c|c|c|}
\hline \multicolumn{3}{|c|}{$\begin{array}{l}\text { Scoping phase (A): Determine the demand for the ES } \\
\text { assessment. }\end{array}$} & \multicolumn{5}{|c|}{$\begin{array}{l}\text { Assessment phase (B): Analyze ES within social-ecological context and impacts of changes (e.g., in land } \\
\text { use, policies, climate) on ES flow, benefits, and trade-offs. }\end{array}$} & \multirow{2}{*}{$\begin{array}{l}\text { Implementation } \\
\text { phase (C). } \\
\text { Step 5: Synthetize } \\
\text { and integrate } \\
\text { information for } \\
\text { decision support }\end{array}$} \\
\hline $\begin{array}{l}\text { Step 1: Specify and } \\
\text { agree with } \\
\text { stakeholders on } \\
\text { problem and relevant } \\
\text { research question }\end{array}$ & $\begin{array}{l}\text { Step 2: Identify ES } \\
\text { beneficiaries and } \\
\text { select ES most } \\
\text { relevant for } \\
\text { decision making }\end{array}$ & $\begin{array}{l}\text { Step 3: Define } \\
\text { information } \\
\text { needs of decision } \\
\text { makers }\end{array}$ & $\begin{array}{l}\text { Step 4a: Assess current } \\
\text { management and } \\
\text { alternative options }\end{array}$ & $\begin{array}{l}\text { Step 4b: Assess role } \\
\text { of biodiversity and } \\
\text { ecosystem } \\
\text { processes for } \\
\text { provision of ES }\end{array}$ & $\begin{array}{l}\text { Step 4c: Assess flow } \\
\text { of ES and how } \\
\text { changes in } 4 a \text { and } 4 b \\
\text { impact ES flow }\end{array}$ & $\begin{array}{l}\text { Step 4d: Determine ES } \\
\text { benefits, values, and ES } \\
\text { trade-offs }\end{array}$ & $\begin{array}{l}\text { Step 4e: } \\
\text { Account for } \\
\text { impacts } \\
\text { beyond land } \\
\text { use and ES }\end{array}$ & \\
\hline $\begin{array}{l}\text { Water shortage } \\
\text { during prolonged } \\
\text { periods of drought } \\
\text { causes conflicts over } \\
\text { water management } \\
\text { between multiple } \\
\text { stakeholders across } \\
\text { multiple scales. } \\
\text { Water uses include: } \\
\text { Water withdrawal by } \\
\text { farmers for irrigation, } \\
\text { by households and } \\
\text { communal water } \\
\text { suppliers for domestic } \\
\text { use (drinking water), } \\
\text { by local users, and } \\
\text { transferred to distant } \\
\text { user regions. } \\
\text { Minimum water flow } \\
\text { required for } \\
\text { ecological processes, } \\
\text { fishery, aquaculture, } \\
\text { and navigation. Water } \\
\text { storage for electricity } \\
\text { generation from } \\
\text { hydropower. } \\
\text { Constructions of dams } \\
\text { caused displacement } \\
\text { of farmers to less } \\
\text { fertile areas. } \\
\text { Lack of coordination } \\
\text { between stakeholder } \\
\text { groups represented in } \\
\text { the Watershed } \\
\text { Committee). }\end{array}$ & $\begin{array}{l}\text { Maintenance of } \\
\text { water flow } \\
\text { benefits: } \\
\text { - domestic water } \\
\text { use by households, } \\
\text { - irrigation by } \\
\text { farmers within and } \\
\text { outside catchment, } \\
\text { - hydroelectric } \\
\text { power generation, } \\
\text { - navigation, } \\
\text { - ecological } \\
\text { processes. } \\
\text { Maintenance of } \\
\text { water quality } \\
\text { benefits domestic } \\
\text { use, irrigation, } \\
\text { livestock health, } \\
\text { aquaculture, } \\
\text { fisheries, and } \\
\text { leisure. } \\
\text { Maintenance of soil } \\
\text { fertility benefits } \\
\text { agricultural } \\
\text { production. } \\
\text { Negative effects } \\
\text { from nutrient } \\
\text { export to river. } \\
\text { Erosion control } \\
\text { benefits navigation } \\
\text { and hydropower } \\
\text { potential besides } \\
\text { other. }\end{array}$ & $\begin{array}{l}\text { Watershed } \\
\text { Committee } \\
\text { requires } \\
\text { information for } \\
\text { renewing its water } \\
\text { management } \\
\text { plan. The plan is } \\
\text { developed for the } \\
\text { next ten years and } \\
\text { involves strategic } \\
\text { decisions on water } \\
\text { allocation. } \\
\text { Information on } \\
\text { options and } \\
\text { effects of: } \\
\text { - distributing } \\
\text { water among } \\
\text { different users, } \\
\text { while ensuring } \\
\text { sufficient water } \\
\text { flow and quality } \\
\text { for maintaining } \\
\text { health of river } \\
\text { ecosystem; } \\
\text { - reducing soil } \\
\text { erosion and } \\
\text { nutrient export; } \\
\text { - identifying } \\
\text { alternative } \\
\text { income sources } \\
\text { related to tourism; } \\
\text { - coping with } \\
\text { conflicts in } \\
\text { prioritization and } \\
\text { decision making. }\end{array}$ & $\begin{array}{l}\text { There is lack of } \\
\text { enforcing existing } \\
\text { regulations over water } \\
\text { use or they show little } \\
\text { effectiveness (e.g., } \\
\text { water price not } \\
\text { signaling its scarcity). } \\
\text { Option 1: Enhanced } \\
\text { coordination between } \\
\text { stakeholder groups. } \\
\text { Option2: Improve water } \\
\text { monitoring for } \\
\text { informing effectiveness } \\
\text { of actions taken. } \\
\text { Option 3: Enhance } \\
\text { existing water } \\
\text { management including } \\
\text { sanitation. } \\
\text { Option 4: Protect and } \\
\text { restore riparian } \\
\text { vegetation for } \\
\text { controlling erosion and } \\
\text { nutrient input. } \\
\text { Option } 5: \text { Enhance soil } \\
\text { nutrients and } \\
\text { adsorption capacity. } \\
\text { Option 6: Diversify } \\
\text { agricultural production } \\
\text { and aquaculture. } \\
\text { Option 7: Use income } \\
\text { from water permits to } \\
\text { support and monitor } \\
\text { current management } \\
\text { and restoration } \\
\text { projects. }\end{array}$ & $\begin{array}{l}\text { Applying field } \\
\text { measurements and } \\
\text { hydrological and } \\
\text { nutrient emission } \\
\text { modeling for } \\
\text { assessing: } \\
\text { Impacts of current } \\
\text { and future land and } \\
\text { water use on water } \\
\text { flow and quality; } \\
\text { Options for } \\
\text { enhancing soil } \\
\text { nutrients and } \\
\text { reducing } \\
\text { sedimentation; } \\
\text { Effect of land use on } \\
\text { water nutrients } \\
\text { (e.g., phosphorus); } \\
\text { Impact of reservoir } \\
\text { management on } \\
\text { macorphytes; } \\
\text { Impacts of different } \\
\text { land use intensities } \\
\text { on biodiversity } \\
\text { (amphibians, and } \\
\text { terrestrial plant } \\
\text { species). } \\
\text { Considering the role } \\
\text { of natural } \\
\text { ecosystems (e.g., } \\
\text { riparian forests) for } \\
\text { water provision and } \\
\text { quality. }\end{array}$ & $\begin{array}{l}\text { Hydrologic and hydro- } \\
\text { economic models are } \\
\text { used for assessing } \\
\text { water availability } \\
\text { under different water } \\
\text { and land-use } \\
\text { scenarios. } \\
\text { The Watershed } \\
\text { Committee aims at } \\
\text { conserving riparian } \\
\text { and spring } \\
\text { ecosystems as they } \\
\text { are found to be of } \\
\text { importance for water } \\
\text { supply and quality. } \\
\text { This option is not only } \\
\text { of ecological relevance } \\
\text { but also highly } \\
\text { political, since it has } \\
\text { been promoted as } \\
\text { alternative to the } \\
\text { contested transfer of } \\
\text { water out of the } \\
\text { catchment. } \\
\text { Trade-off: Actions for } \\
\text { soil improvement } \\
\text { may promote further } \\
\text { conversion of natural } \\
\text { vegetation (Caatinga } \\
\text { reserves) to cropland } \\
\text { with negative impacts } \\
\text { on biodiversity and } \\
\text { water availability. }\end{array}$ & $\begin{array}{l}\text { Who are winner and } \\
\text { loser of water and land } \\
\text { management strongly } \\
\text { depends on } \\
\text { negotiations and power } \\
\text { relations among users. } \\
\text { Several water claims are } \\
\text { mutually exclusive. } \\
\text { Farmers benefit from } \\
\text { irrigation and water for } \\
\text { livestock production; } \\
\text { Fishermen benefit from } \\
\text { maintenance of water } \\
\text { flow and quality for fish } \\
\text { production. } \\
\text { Villages and towns } \\
\text { benefit from supply for } \\
\text { domestic use. } \\
\text { Local and indigenous } \\
\text { communities benefit } \\
\text { from intrinsic and } \\
\text { spiritual value of natural } \\
\text { landscape. } \\
\text { Companies benefit from } \\
\text { water for hydroelectric } \\
\text { power generation, } \\
\text { industries, mining, water } \\
\text { diversion projects, } \\
\text { transport (waterways), } \\
\text { tourism. } \\
\text { Water shortage and } \\
\text { erosion has multiple } \\
\text { negative impacts and } \\
\text { costs to different users. }\end{array}$ & $\begin{array}{l}\text { Water } \\
\text { shortage and } \\
\text { land } \\
\text { degradation } \\
\text { drives } \\
\text { migration to } \\
\text { towns for } \\
\text { alternative } \\
\text { income } \\
\text { options. } \\
\text { Construction of } \\
\text { dams causes } \\
\text { expulsion of } \\
\text { people from } \\
\text { the region. } \\
\text { Distant water } \\
\text { users } \\
\text { benefiting } \\
\text { from water } \\
\text { transfer, while } \\
\text { also involving } \\
\text { equity } \\
\text { concerns. } \\
\text { Change in } \\
\text { traditional } \\
\text { water use also } \\
\text { has cultural } \\
\text { effects on local } \\
\text { and indigenous } \\
\text { people. }\end{array}$ & $\begin{array}{l}\text { The project is } \\
\text { developing water and } \\
\text { land use models } \\
\text { which test scenarios } \\
\text { of different land and } \\
\text { water management } \\
\text { options for decision } \\
\text { support. } \\
\text { Further } \\
\text { recommendations to } \\
\text { the Watershed } \\
\text { Committee include: } \\
\text { Support democratic, } \\
\text { inclusive and } \\
\text { transparent decision- } \\
\text { making processes } \\
\text { allowing for effective } \\
\text { participation of all } \\
\text { stakeholder groups. } \\
\text { Harmonization of and } \\
\text { easy access to } \\
\text { existing water } \\
\text { monitoring programs, } \\
\text { data and statistics. } \\
\text { Capacity building } \\
\text { related to importance } \\
\text { of riparian } \\
\text { ecosystems: assess } \\
\text { and monitor ongoing } \\
\text { restoration projects } \\
\text { with careful } \\
\text { consideration of } \\
\text { ecosystem services. }\end{array}$ \\
\hline
\end{tabular}

is often constrained by the lack of resources and information. It is also not necessarily required in every decision context. For the case of the LEGATO project in Vietnam, for example, tourism and industrial development are likely to increase in importance for household income, but up to now they play a secondary role within the assessment, because the main focus is on enhancing pest control in rice farming systems (step 2, Fig. 4).

Whether the entire bundle of ES or only a subset of prioritized ES should be assessed is determined by the problem to be addressed (step 1), the different stakeholders and the decisions to be informed (step 3), and available methods and resources, including capacities, budget, and time. However, synergies and trade-offs involved in decisions and differences in preferences and impacts between stakeholder groups should be considered.

The perception of ES and related terminology can differ between stakeholder groups, localities, and cultural contexts. The ES concept can serve as an analytical tool for translating context specific terms into an agreed ES classification system (e.g., Haines-Young and Potschin 2012). For example, in stakeholder consultations of the LEGATO project, it was not the goal to educate stakeholders about the ES concept, but to collect their knowledge on the benefits they receive from ecosystems expressed in their own terms. The ES concept was then used to unify the various terms and enable synthesis and further analysis. Translation back into stakeholder-specific terms should be considered when disseminating results during the assessment process (e.g., in step 5).

\section{Step 3: Define information needs of decision makers}

Knowledge gaps in decision-making processes have to be addressed to ensure that an ES assessment generates relevant information (TEEB 2012; Table 1). Identifying options for integrating ES-related knowledge in ongoing decision-making processes supports the uptake of assessment results in decision processes (Ruckelshaus et al. 2015).

For example, the regional Watershed Committee of the São Francisco River in Brazil is in the process of developing a new water management plan for the next 10 years. In a series of stakeholder workshops, members of the committee identified gaps in understanding the impacts of decisions on water-related ES. Sharing knowledge among all stakeholders helped to build trust. As a consequence the Watershed Committee asked the INNOVATE project to contribute to filling the knowledge gaps. Thus, INNOVATE used hydrological models to inform about the amount of water available for irrigation, supply of drinking water, electricity generation, and critical ecological processes under different scenarios of decision making and climate change.

In the Tarim Basin in China, there is the need to generate a common understanding of impacts and trade-offs involved in decisions on land and water use across the region to inform the 
Fig. 6. Problem-oriented approach for assessing ecosystem services (ES): the case of the SuMaRiO project in the Tarim River Basin in China (Rumbaur et al. 2015).

\begin{tabular}{|c|c|c|c|c|c|c|c|c|}
\hline \multicolumn{3}{|c|}{$\begin{array}{l}\text { Scoping phase (A): Determine the demand for the ES } \\
\text { assessment. }\end{array}$} & \multicolumn{5}{|c|}{$\begin{array}{l}\text { Assessment phase (B): Analyze ES within social-ecological context and impacts of changes (e.g., in land } \\
\text { use, policies, climate) on ES flow, benefits, and trade-offs. }\end{array}$} & \multirow{2}{*}{$\begin{array}{l}\text { Implementation } \\
\text { phase (C). } \\
\text { Step 5: Synthetize } \\
\text { and integrate } \\
\text { information for } \\
\text { decision support }\end{array}$} \\
\hline $\begin{array}{l}\text { Step 1: Specify and } \\
\text { agree with } \\
\text { stakeholders on } \\
\text { problem and relevant } \\
\text { research question }\end{array}$ & $\begin{array}{l}\text { Step 2: Identify ES } \\
\text { beneficiaries and } \\
\text { select ES most } \\
\text { relevant for } \\
\text { decision making }\end{array}$ & $\begin{array}{l}\text { Step 3: Define } \\
\text { information needs } \\
\text { of decision } \\
\text { makers }\end{array}$ & $\begin{array}{l}\text { Step 4a: Assess current } \\
\text { management and } \\
\text { alternative options }\end{array}$ & $\begin{array}{l}\text { Step 4b: Assess } \\
\text { role of biodiversity } \\
\text { and ecosystem } \\
\text { processes for } \\
\text { provision of ES }\end{array}$ & $\begin{array}{l}\text { Step 4c: Assess flow of } \\
\text { ES and how changes in } \\
4 a \text { and } 4 b \text { impact ES } \\
\text { flow }\end{array}$ & $\begin{array}{l}\text { Step 4d: Determine ES } \\
\text { benefits, values and } \\
\text { ES trade-offs }\end{array}$ & $\begin{array}{l}\text { Step 4e: } \\
\text { Account for } \\
\text { impacts } \\
\text { beyond land } \\
\text { use and ES }\end{array}$ & \\
\hline $\begin{array}{l}\text { Irrigation of cotton } \\
\text { causes land } \\
\text { degradation and } \\
\text { increases the risk of } \\
\text { desertification. } \\
\text { Melting glaciers of } \\
\text { Tien Shan Mountains } \\
\text { are main water } \\
\text { source. Water flow } \\
\text { from glaciers is } \\
\text { expected to decline } \\
\text { after } 2050 \text { due to } \\
\text { climate change. } \\
\text { Overuse of irrigation } \\
\text { is having multiple } \\
\text { negative impacts on } \\
\text { ecosystems including: } \\
\text { salinization of soils } \\
\text { and river water, } \\
\text { changes in ground } \\
\text { water level, soil } \\
\text { degradation leading to } \\
\text { productivity loss of } \\
\text { agricultural land, } \\
\text { degradation of natural } \\
\text { forests. } \\
\text { Loss of natural forest } \\
\text { causes biodiversity } \\
\text { loss, reduction in } \\
\text { storm protection, and } \\
\text { increase in wind } \\
\text { erosion and sand } \\
\text { drift. }\end{array}$ & $\begin{array}{l}\text { Most important ES } \\
\text { of the Tarim River } \\
\text { Basin include: } \\
\text { Water for } \\
\text { agriculture, } \\
\text { industry, } \\
\text { households, and } \\
\text { natural ecosystems; } \\
\text { Fiber: } 40 \% \text { of } \\
\text { Chinas cotton is } \\
\text { produced in the } \\
\text { region, heavily } \\
\text { relying on water for } \\
\text { irrigation. } \\
\text { Food: water } \\
\text { sustains irrigation } \\
\text { agriculture and } \\
\text { livestock. } \\
\text { Natural forests } \\
\text { provide storm } \\
\text { protection and } \\
\text { erosion control, } \\
\text { mitigating sand } \\
\text { drift, sandstorms, } \\
\text { and desertification. } \\
\text { Habitat for } 60 \% \text { of } \\
\text { global population of } \\
\text { Euphrat poplar } \\
\text { (Populus } \\
\text { euphratica). } \\
\text { Trade-off in water } \\
\text { use for irrigation } \\
\text { vs. water needed } \\
\text { for maintaining } \\
\text { natural vegetation. }\end{array}$ & $\begin{array}{l}\text { Information on ES } \\
\text { is requested by } \\
\text { institutional } \\
\text { stakeholders in } \\
\text { Xinjiang Region: } \\
\text { Water Resources } \\
\text { Bureau and Tarim } \\
\text { River Basin } \\
\text { Management } \\
\text { Bureau: How does } \\
\text { climate change } \\
\text { impact glacier } \\
\text { melt, water flow, } \\
\text { and future water } \\
\text { availability? } \\
\text { Agriculture } \\
\text { Department: How } \\
\text { can salinization of } \\
\text { soils be reduced? } \\
\text { Forestry } \\
\text { Administration: } \\
\text { How do changes in } \\
\text { groundwater } \\
\text { impact natural } \\
\text { forests? } \\
\text { Environmental } \\
\text { Protection } \\
\text { Department: } \\
\text { What are options } \\
\text { for reducing } \\
\text { salinization and } \\
\text { desertification? }\end{array}$ & $\begin{array}{l}\text { Comparing impacts of } \\
\text { different scenarios of } \\
\text { climate change and } \\
\text { land use on hydrology } \\
\text { and socio-economy: } \\
\text { Climate change: } \\
\text { Assessing impact of a) } \\
\text { extreme, b) moderate, } \\
\text { and c) low rise in global } \\
\text { temperature on } \\
\text { hydrology of the Tarim } \\
\text { Basin. } \\
\text { Land use and socio- } \\
\text { economic scenarios: a) } \\
\text { maximizing cotton } \\
\text { production versus b) } \\
\text { complete protection of } \\
\text { natural vegetation and } \\
\text { c) mosaic landscape of } \\
\text { cotton production with } \\
\text { natural vegetation. } \\
\text { Testing alternatives to } \\
\text { cotton production: } \\
\text { Indian hemp } \\
\text { (Apocynum sp.) is a salt } \\
\text { tolerant plant that can } \\
\text { be used for fiber } \\
\text { production. It can be } \\
\text { used for restoring saline } \\
\text { soils. Economically } \\
\text { viable production is } \\
\text { being tested. }\end{array}$ & $\begin{array}{l}\text { Assessment of: } \\
\text { Climate change } \\
\text { using climate } \\
\text { models for } \\
\text { predicting changes } \\
\text { in precipitation and } \\
\text { temperature; } \\
\text { Hydrology using } \\
\text { model MIKE HYDRO } \\
\text { for computing water } \\
\text { discharge, water use, } \\
\text { and allocation. } \\
\text { Agricultural } \\
\text { changes using agro- } \\
\text { economic models } \\
\text { for comparing } \\
\text { productivity of } \\
\text { cotton on "healthy" } \\
\text { soils and on saline } \\
\text { soils with the } \\
\text { productivity of the } \\
\text { alternative fiber } \\
\text { plant Apocynum sp. } \\
\text { Forest changes } \\
\text { analyzing state of } \\
\text { forests on shallow } \\
\text { and deep ground- } \\
\text { water levels, forest } \\
\text { distribution, and use } \\
\text { of fuelwood. } \\
\text { Desertification } \\
\text { analyzing area } \\
\text { affected. }\end{array}$ & $\begin{array}{l}\text { Assessing impact of } \\
\text { changes in climate and } \\
\text { land use on ES flow: } \\
\text { Water provision from } \\
\text { glacial melt compared } \\
\text { with water demand for } \\
\text { irrigation agriculture, } \\
\text { maintenance of natural } \\
\text { ecosystems. } \\
\text { Fiber production: } \\
\text { Compare yields of cotton } \\
\text { with Apocynum sp. } \\
\text { Fuelwood: Assess } \\
\text { harvest of fuel wood in } \\
\text { riparian forest. } \\
\text { Storm and erosion } \\
\text { control by forests: } \\
\text { Assess avoidance of sand } \\
\text { drift, soil erosion, } \\
\text { sandstorm, and avoided } \\
\text { damage to infrastructure } \\
\text { (e.g., roads). } \\
\text { Habitat: Asses species } \\
\text { composition of forests, } \\
\text { comparing different } \\
\text { stages of forest use and } \\
\text { degradation. } \\
\text { Recreation: Assess } \\
\text { aesthetic appreciation by } \\
\text { visitors. }\end{array}$ & $\begin{array}{l}\text { Water provision } \\
\text { benefits agriculture, } \\
\text { industry, domestic use } \\
\text { (e.g., drinking water). } \\
\text { Fiber from cotton } \\
\text { provides income to } \\
\text { small private and large } \\
\text { state farms and large- } \\
\text { scale investors. } \\
\text { Fuel wood is used by } \\
\text { households for } \\
\text { heating and cooking. } \\
\text { Storm protection, } \\
\text { erosion control by } \\
\text { forests: estimating } \\
\text { avoided damage to } \\
\text { roads. } \\
\text { Provision of habitat } \\
\text { species abundance. } \\
\text { Aesthetics: benefits to } \\
\text { tourism. } \\
\text { Trade-offs: } \\
\text { Apocynum sp. finds } \\
\text { lower acceptance by } \\
\text { farmers than cotton as } \\
\text { production is more } \\
\text { expensive providing } \\
\text { less income. Farmers } \\
\text { prefer alternative } \\
\text { water-intense crops } \\
\text { e.g. Chinese dates. }\end{array}$ & $\begin{array}{l}\text { External } \\
\text { effects are not } \\
\text { addressed in } \\
\text { this study but } \\
\text { include: } \\
\text { Water use and } \\
\text { environmental } \\
\text { impacts by } \\
\text { other } \\
\text { economic } \\
\text { sectors such } \\
\text { as oil and gas } \\
\text { mining; } \\
\text { Impact of } \\
\text { desertification } \\
\text { on other } \\
\text { regions and } \\
\text { infrastructure; } \\
\text { Health effects } \\
\text { by dust due to } \\
\text { wind erosion; } \\
\text { Potential land- } \\
\text { use conflicts } \\
\text { effecting } \\
\text { minorities; } \\
\text { Effects of land } \\
\text { use and land } \\
\text { degradation } \\
\text { on migration. }\end{array}$ & $\begin{array}{l}\text { Findings include: } \\
\text { By } 2060 \text { glaciers are } \\
\text { likely to have } \\
\text { disappeared due to } \\
\text { climate change, which } \\
\text { is likely to lead to a } \\
\text { decrease in runoff } \\
\text { and water shortage in } \\
\text { the Tarim River (Sorg } \\
\text { et al. 2012). } \\
\text { Based on models a } \\
\text { Decision Support Tool } \\
\text { (DST) is developed } \\
\text { allowing institutional } \\
\text { stakeholders to } \\
\text { evaluate possible } \\
\text { consequences of } \\
\text { scenarios of land and } \\
\text { water use. Impacts of } \\
\text { different scenarios on } \\
\text { ES provision are rated } \\
\text { (good, medium, poor); } \\
\text { The DST has mainly } \\
\text { educational } \\
\text { purposes; } \\
\text { Simple solutions do } \\
\text { not exist. Decision } \\
\text { involves trade-offs in } \\
\text { agriculture and nature } \\
\text { conservation. The DST } \\
\text { can inform decision } \\
\text { making on likely } \\
\text { impacts on ES } \\
\text { provision. }\end{array}$ \\
\hline
\end{tabular}

development of the five-year-plan at a national and provincial level. The SuMaRiO project involves multiple institutions at regional level, each with competing interests and responsibilities in managing water distribution, agricultural production, forests, and biodiversity conservation (step 3, Fig. 6). Adequate and sensitive management of tensions is critical for developing a concerted strategy for the entire Tarim Basin. Hydrological models operating at a basin scale were chosen to better understand the effects of different options for water distribution and land use (step 4). Based on this, a decision support tool was developed, allowing institutions to test different decision scenarios (step 5). The assessment process also contributes to enhancing transparency and communication among different stakeholder groups.

In Vietnam, rice farmers and authorities expressed their interest in low-cost measures for stabilizing or enhancing rice yields, reducing pre- and postharvest losses, in particular through pest control, reducing water pollution from pesticide use, enhancing soil nutrients, and improving income and livelihood. The LEGATO project compared traditional and conventional farming systems for biological pest control, rice yields, nutrient cycling in soils, and impacts on water quality (step 4, Fig. 4). The analysis of the ecological processes related to biological pest control required species sampling over several growing seasons. This focus mainly determined the design, spatial scale, and timing of the assessment. Interactions with other practices that affect the farming system, e.g., tourism or forestry, were also investigated.

Careful consideration of the actual information needs by decision makers is important to ensure that ES assessments apply indicators and methods, which provide the type and detail of information required for a specific decision. At the same time, the expectations of stakeholders and decision makers about what an ES assessment can deliver need to be kept realistic to ensure that assessment results are used appropriately and that misinterpretations and disappointments are avoided.

\section{Assessment phase (B)}

Step 4: Analyze ES within social-ecological context and impacts of changes, e.g., in land use, policies, climate, on ES flow, benefits, and trade-offs.

The previous steps provide the focus for the social-ecological analysis in step 4, which is divided into five substeps compatible with other SES approaches (Fig. 2): the assessment of current and alternative management options (4a), ecological factors relevant for producing ES (4b), the flow of ES (4c), ES benefits and trade-offs (4d), and impacts beyond land use and ES (4e; Table 2). 
Table 2. Examples of questions, actions, and indicators for assessment phase (B).

Assessment phase (B): Analyze ecosystem services (ES) within social-ecological context and impacts of changes, e.g. in land use, policies, climate, on ES flow, benefits, and trade-offs.

Step 4a: Assess current management and alternative options

What are historical and current land-use practices and which policies and institutions influence change?

Analyzing how policies and institutions influence land-use practices to identify options for improving resource use and governance (e.g., Rathwell and Peterson

How are future changes expected to influence land use and ES provision?

What formal and informal policies, norms, and rules influence land-use decisions?

Providing evidence from success stories in other regions to identify alternative options. For example Goldman et al. (2008) found that using ES information had a positive influence

Which drivers influence land-use practices and policies, e.g., cultural or economic drivers?

What are potential alternative land-use options and policies?

Developing social-ecological models and
scenarios of future changes together with on the success of conservation projects. stakeholders and decision makers for understanding drivers for ES provision and

Which freedom of choice do local farmers have?
Types of land-use practices and change over time;

Laws, regulations, and financial mechanisms such as subsidies, taxes, or fines; Institutions governing land use;

Developments in market price of crops and market access;

Formal regulations, e.g., related to pesticides and nutrients use;

Traditional and informal rules, e.g., on cropping cycles, types of crops used; Cultural rules and norms, e.g., rites related to land use;

Level of decision making, by individual farmer or by central government.

Step 4b: Analyze role of biodiversity and ecological processes for provision of ES Which elements of biodiversity and ecosystem processes are important for ES provision over an extended period of time?

Choosing methods that resonate with decision makers and adapting them to particular information needs to ensure credibility of ES data for decision making. For example, mapping and modeling of ES can be targeted Model influence of drivers on biodiversity and

How do land use and other relevant drivers impact biodiversity and ecosystems, e.g., to specific stakeholder needs (e.g., Petter et al. changes in population, policies, markets, and $\quad 2012$, Crossman et al. 2013).

climate?

Using in-situ field measurements for

What are likely impacts of alternative land-use monitoring biodiversity and ecosystem options and policies on biodiversity and processes, e.g., species presence or ecosystem processes?

hydrological monitoring

Analyzing historical trends in land use and conditions of ecosystems using remote sensing.

Step 4c: Assess flow of ES and how changes in 4a and 4b impact ES flow

How do biodiversity and ecosystem processes contribute to the provision of ES?

Assessing impacts of changes in management on ES flow, using integrative methods and tools, including socioeconomic and ecological

How do changes in land use and other drivers influence ES flow, e.g., changes in population, policies, markets, and climate?

models (e.g., Bagstad et al. 2013).

Modeling impacts of land-use change on ES flow such as erosion, sediment load, nutrient

How would alternative land-use options and/or concentration in water or water availability (e. policies impact ecosystems and ES flow?

g., Villa et al. 2014).

Assessing impact of changes in crop growth on yield or changes in species composition on spread of pests.

Assessing impact of changes in forest use on carbon stocks, availability of wood for fuel and construction, bush meat, medicinal plants, etc.

Water flow in river under different land use, land cover, or climate scenarios;

Comparing crop yield for different stages of soil degradation;

Abundance of pests in relation to species composition;

Water quality, e.g., nutrient or sediment content, for different scenarios of land use and cover; Erosion control by vegetation for different land-use scenarios;

Carbon sequestration by forest under different forest management options.

Step 4d: Determine ES benefits, values, and ES trade-offs resulting from changes in 4a-4c 
Who are ES beneficiaries?

Who are recipients of disbenefits?

What are the ES benefits?

What are the ES disbenefits?

Which social and cultural values are affected positively and negatively by the service/ disservice?

Which socioeconomic values are affected among the different stakeholder groups?

What human inputs, e.g., knowledge, skills, resources, costs, etc., are required for accessing ES?

Which indicators and methods for assessing the benefits/disbenefits of ES are relevant and meaningful to different stakeholders and decision makers?

Step 4e: Impacts beyond land use and ES Which other sectors or institutions beyond lan use are affected by changes in ES flow and benefits/disbenefits?

Which cultural and social impacts occur because of changes in ES,e.g., impacts on traditions, norms, rituals?
Assessing benefits and disbenefits of ES bundles for different stakeholder groups and land-use types (Raudsepp-Hearne et al. 2010, Goldstein et al. 2012, Martín-López et al. 2014).

Using multicriteria-analysis and cost-benefit analysis to account for both qualitative and quantitative ES information in assessing the impacts of land-use changes on human wellbeing (e.g., Sijtsma et al. 2013).

Assessing impacts on social and cultural values such as status, sense of place, social relations (e.g., Chan et al. 2012a, b)

Assessing monetary and nonmonetary values of ES (e.g., Christie et al. 2012, Viglizzo et al. 2012).

Mapping cultural ES (e.g., Plieninger et al. 2013).

Analyzing impacts on education, social norms, traditional practices, rituals, social structures.

Identifying links to other sectors and infrastructure related to energy, transport, communication, etc.

Assessing changes in distribution of wealth and income, political stability and social security, self-determination vs. transfer dependency.
Impact of changes in crop yield on income and status of farmers and decision makers;

Impact of changes in pests on yield, income, and subsequent changes in land management;

Impacts of changes in water availability on water user, e.g., changes in water price, changes in crop yield;

Health benefits, e.g., due to improvement in water quality;

Health damage cost;

Impact of changes in forest cover on erosion, hunting success, carbon stocks;

Changes in water treatment costs; saved costs of sediment removal from reservoirs for hydropower production.

Educational benefits and capacity building because of assessment process; access to new knowledge and technology;

Behavioral changes of land user, e.g., crowding out effects (Rode et al. 2015);

Changes in access to infrastructure, markets, and communication;

Income distribution patterns;
Step 4a: Assess current management and alternative options Identifying policies and management options requires an understanding of the current land-use policies and practices within their socioeconomic and cultural context (Cowling et al. 2008, Ostrom 2009, Chan et al. 2012a). Within ecological limits, landscapes offer a range of potential land-use options and configurations. Which of the land use options are implemented and which of the ES benefits are appropriated and by whom partly depends on the ability of the different stakeholder groups and beneficiaries to influence land-use decisions (Spangenberg et al. 2014b). Social, cultural, and economic processes shape ES generation, with power relations, property and access rights, investments of time, labor, and resources determining the ES potential realized across a landscape.

In the Tarim River Basin in China, land-use decisions are centralized but involve multiple government institutions (Land and Resources Bureau and departments of Agriculture, Forestry, and Environmental Protection) that make decisions at the regional level following guidelines by the central government. Complex trade-offs exist in land and water use for cotton production, hydropower generation, forestry, and conservation of natural habitats (e.g., Feike et al. 2015). To better understand the impacts of different land-use options, scenarios were developed including climate change with high and low water availability, and land use with different intensities of cotton production and nature conservation. In field experiments, alternatives to irrigation-intense cotton production were tested using the salt-tolerant plant Apocynum sp. This plant is suitable for fiber production and can be used for the restoration of degraded agricultural soils. Throughout the assessment process interviews and discussions with stakeholders informed the development and testing of the different options.

In the case of the São Francisco watershed in Brazil, analyses of past and current water governance found that comprehensive water policies already exist for addressing water distribution issues, especially at the federal level. However, the implementation and enforcement of these policies is weak and the water monitoring is inadequate to measure the effectiveness of policies. INNOVATE addressed these immediate information needs of the Watershed Committee by developing guidance on implementation of existing policies and improving water monitoring (step 5).

LEGATO's ES assessment compared traditional and conventional rice farming systems for factors that impact income and livelihoods of farmers. This included institutional settings and world views that may guide different land management decisions, biological pest control, rice yields, and nutrient cycling in soils (step 4a, Fig. 4). 
In the case of the SuLaMa project in Madagascar, decisions of farmers and smallholders are largely based on traditional knowledge (step 4a, Fig. 3). Crops are primarily cultivated for subsistence, with surpluses being traded as a source of income. Besides crops, livestock plays an important role for people's livelihood. It provides a fallback resource in periods of crop failures and also determines social status. Current land use leads to ecosystem degradation and encroachment in the Tsimanampetsotsa National Park. This situation is aggravated by cattle thieves driving farmers to graze their livestock in forested areas. Thus, the SuLaMa project analyzed the drivers of degradation, their impacts on biodiversity and ES provision, and explored options of more sustainable land use. Besides others, this includes fodder production for livestock as means for reducing grazing pressure and the use of home gardens as means of diversifying sources of income.

\section{Step 4b: Assess role of biodiversity and ecosystem processes for} provision of $E S$

In this step, ecological processes and biodiversity indicators relevant for the provision of the prioritized ES are identified and analyzed. This includes biophysical measurements, modeling of ecological processes, and biodiversity assessments as well as characterization of relevant drivers. Again, multiple sources of knowledge should be taken into account including scientific, traditional, and indigenous knowledge. Biophysical assessment methods are numerous, and factors influencing the choice of methods include: the type of biophysical indicators required for addressing the information needs, available expertise and resources, available data, and extent to which primary data have to be measured in the field.

In the Tarim Basin in China, the SuMaRiO project used the hydrological model MIKE HYDRO for estimating water discharge and allocation for irrigation. Cotton yields on intact soils were compared with yields on degraded soils, and productivity of the more salt-tolerant crop Apocynum sp. were tested in the field to inform model simulations of alternative crop production. Methods of forest monitoring were used to assess how forest biodiversity and its role for erosion control are impacted by changes in groundwater levels.

In INNOVATE, the hydrological model SWIM and the nutrient emission model MONERIS were calibrated and adjusted for the São Francisco River. The MAgPIE model was used to estimate future land use under climate change. Hydro-economic analysis was performed for a subregion of the catchment. A species distribution model of the semiarid Caatinga vegetation was set up with Maxent. Although these models mainly use secondary data, primary data on biodiversity and alternative land use options were collected in the field.

LEGATO in Vietnam analyzed the role of biodiversity for pest control, conducting inventories of species, e.g., of parasitoids or damsel- and dragonflies, that control pests. Impacts of fertilizers and pesticides on ecological processes were investigated via field inventories of pollinators, native and alien plant species, soil organisms, and nutrient cycles. This was accompanied by surveys among farmers to assess productivity of rice fields for the different farming systems. The analysis of the ecological processes was the main factor determining the design, spatial scale, and timing of the assessment.
Step 4c: Assess flow of ES and how changes in $4 a$ and $4 b$ impact ES flow

In this step, the interplay between social (4a) and ecological factors (4b) and their role for the production and flow of ES is assessed. A causal relationship between ecological factors and the provision of ES is often anticipated, but it is rarely proven or quantified (Carpenter et al. 2009, Reyers et al. 2013). Proxy indicators are often used in cases where direct measurements of ES are missing or for simplifying the analysis, e.g., changes in forest cover as proxy for carbon sequestration. Additional validation is required in case proxies are used to transfer results across different sites.

Given the complexity involved in social-ecological systems, computer-based models are often the first choice for analyzing climate-change impacts, drivers of land-use change, their impacts on ES flow, and alternative land-use scenarios. This is in particular true for large-scale assessments as undertaken by INNOVATE and SuMaRiO (Figs. 5 and 6; e.g., Krysanova et al. 2015). Validating models based on empirical data and discussing their plausibility with scientists and stakeholders is critical to ensure that model outputs provide relevant information for decision making. In the Tarim Basin in China, hydrological modeling combined with stakeholder consultations helped inform decision makers about potential impacts of land-use decisions on water availability. Through this process the relevance of forest conservation for protecting infrastructure and agricultural land from desertification was communicated to respective stakeholders.

Field surveys and experiments allow ground truthing the assumptions on ES flows. In Madagascar, the SuLaMa project used household surveys to analyze the relevance of ES for household income, including yields of different crop varieties, productivity of home gardens, fodder production using Samata (Euphorbia stenoclada), and use of wild plants. Inventories of insect species in rice fields in Vietnam elucidated the benefits that local communities obtain from traditional farming practices that support natural pest control (LEGATO, Fig. 4).

Step 4d: Determine ES benefits, values, and ES trade-offs Valuation of biodiversity and ES depends on the perception of stakeholders that benefit from ES or suffer disbenefits (Görg et al. 2014). There are multiple values that stakeholders can attach to biodiversity and ES, including social, cultural, and economic (monetary and nonmonetary) values (Chan et al. 2012a, TEEB 2012). Demonstrating these values with analytical methods in quantitative and qualitative terms can be a challenge; in particular, when it comes to spiritual and cultural values, public goods, and future generations. The types of values to be assessed and the choice of methods and indicators should be tailored to each specific decision.

Although increasing in popularity, monetary valuation of ES is not necessarily required or useful in every decision context. Alternative and complementary methods for addressing social and cultural values can be more relevant to decision makers (Limburg et al. 2002, Daily et al. 2009, Abson and Termansen 2011, TEEB 2012, Chan et al. 2012b, Ruckelshaus et al. 2015, Sijtsma et al. 2013). Multicriteria analysis is an option for integrating qualitative and quantitative information on values in 
decision making (e.g., Fontana et al. 2013). There is also an increasing number of tools for data integration (Bagstad et al. 2013).

In particular, traditional land-use practices cater multiple values. Rice farming in Vietnam is not only a source of food and income, but it is deeply interlinked with local culture and traditions, which developed around rice farming over generations. Hence, in the LEGATO project, alternative rice-farming practices were not only evaluated for their benefits in terms of income and environmental impacts, but also for their impacts on local culture and identity. Rice farming systems based on traditional knowledge are expected to account for ecological processes, using locally adapted crop varieties, which require less input of artificial fertilizer and pesticides. Such systems are expected to enhance natural pest control, thus requiring less chemical inputs, which in turn reduces related costs and benefits water quality. Traditional farming is also promoting a sense of place by strengthening local traditions and social bonds (Tekken and Settele 2014). This has potential benefits for tourism, which brings new income sources to the region, but can also exert stress on traditions and social bonds. Accessing markets for organic products can potentially provide a long-term perspective also for younger rice farmers.

Similarly, in Madagascar, land-use practices are strongly linked to local culture through traditional knowledge and religious beliefs. Besides analyzing crop yield, food availability, and cash income, the SuLaMa project also accounted for cultural values involved in each of the analyzed land-use practices. Wild plants do not only serve as food or medicine but also fulfil important roles in traditions and rites. The number of livestock determines the social status of households, providing an incentive to increase livestock numbers, which can enhance grazing pressure.

In the case of watershed management addressed by INNOVATE in Brazil and SuMaRiO in China, ES valuation targets more longterm investment decisions across regional scales. Stakeholders were asking for quantitative information on water flow, crop yield, costs of water provision, costs of ecosystem degradation, and impacts on income. ES valuation was used to identify the winners and losers of different watershed management strategies. In the Tarim Basin in China, SuMaRiO project assessed the ecological and economic potential of Apocynum sp. as an alternative to cotton production (Thevs et al. 2012). The value of natural forests for reducing wind erosion and desertification was analyzed by estimating avoided costs from reduced loss in agricultural land and reduced infrastructure maintenance, e.g., cleaning sand from roads.

\section{Step 4e: Account for impacts beyond land use and ES}

Decision making within the assessed social-ecological system can have external effects on other social-ecological systems (Ostrom 2009). Shifts in land use can impact stakeholder sectors and landuse systems within and outside the study region. Valuation of ES can have impact on cultural values or behavior. For example, introducing monetary values as an argument for conservation of biodiversity can replace cultural and intrinsic motivations for conservation (crowding-out effects; Rode et al. 2015).

In the assessment of watersheds in Brazil (INNOVATE) and China (SuMaRiO), it is recognized that changes in land and water use greatly impact migration of people in and out of the region, although it is not the central focus of the assessment. The INNOVATE project acknowledged plans for artificial water transfer to regions outside the watershed and the severe impacts this can have on the future development of the entire catchment. Because of the lack of transparency regarding the details of these plans, this factor is subject to speculation. In the Tarim Basin in China, mining of oil and gas is an important water user, but this sector was beyond the scope of the SuMaRiO project because of limited resources and political reasons. Although cattle theft is a major problem in Madagascar, it was not the focus of the SuLaMa project to assess behavioral changes of cattle thieves in response to changes in cattle production. In Vietnam, industrial development impacts income opportunities, causing migration of young people to cities and a decline in farming population. This issue is documented by the LEGATO project but not assessed in detail because these drivers are beyond the project's influence.

Although such external effects cannot always be analyzed in detail, it is critical to recognize their existence. They substantiate the discussion of uncertainties of the findings and help in embedding the findings of ES assessments into the larger decision context.

\section{Implementation phase (C)}

Step 5: Synthetize and integrate information for decision support Step 5 focuses on the use of ES information for decision support based on the synthesis of information generated in the previous steps (Table 3). The outcomes of ES assessments depend on the information needs defined in scoping phase A and need to be adapted to the particular ecological, socioeconomic, and cultural context. Assessment results can help change stakeholder perspectives and trigger changes in the management of biodiversity and ES (Ruckelshaus et al. 2015). Whether this change is for better or worse depends on how the information is used and by whom. Avoiding the fact that ES information leads to adverse impacts, e.g., the commodification and exploitation of nature (Turnhout et al. 2013, Schröter et al. 2014), requires broad stakeholder participation and transparency in defining and using ES information (Chan et al. 2012a, Jax et al. 2013).

Integrating ES information into decision making and changing land management to more sustainable practices require adaptive management (Cowling et al. 2008), involving an iterative and participatory process of prioritizing management actions, monitoring their performance, and adjusting management practices in accordance with the defined objectives (MartinezHarms et al. 2015). The outcome can be as unique as the assessment process itself, depending on the specific socialecological context. Hence, guidance on integrating ES information into decision making can only remain general. However, science-practice partnerships, involving close collaboration of practitioners and scientists from outset of the assessment, can help generate user-inspired and user-relevant knowledge that promotes effective management on the ground (Ntshotsho et al. 2015).

In the INNOVATE project, guidelines for the watershed management of the São Francisco River in Brazil were discussed with stakeholders to improve water monitoring and inform existing policies and restoration efforts. Collaboration with local and regional research organizations ensures capacity building for 
Table 3. Examples of questions, actions, and indicators for implementation phase (C).

Implementation phase $(\mathrm{C})$

Questions

Step 5: Synthetize and integrate information for decision support

How to communicate the generated ecosystem Promoting science-practice partnerships services (ES) information, so it is adopted by stakeholders?

from the start to enable codesign of userinspired and user-relevant knowledge (Milner-Gulland et al. 2010, Ntshotsho et al.

Are there windows of opportunities for bringing assessment results to the attention of key decision makers, institutions, or including it in public debates? 2015 ).

How can the generated ES information trigger changes in policies and practices? How to ensure that these changes improve the sustainability of land use?

Are there important knowledge gaps that require an iteration of assessment steps?

\author{
us
}

Promoting use of assessment results through user-adapted decision support tools such as participatory models, maps, guidelines, user- The type of ES information and tools used by targeted publications, and web sites (e.g., Liekens et al. 2013).

Consulting stakeholders, decision makers, and experts on the use of ES information.

Establishing monitoring system for tracking positive and negative changes.
Indicators (qualitative \& quantitative)

Awareness of stakeholder groups on availability of ES information, e.g., through the use of assessment results or published reports.

Monitoring of qualitative and quantitative changes in ES using indicators, e.g., for water quality, sediment load, crop yield, carbon stock, etc. (e.g., Feld et al. 2009). stakeholders in decision processes.

Repeating assessment steps if necessary.

future assessments in the region. Supporting ongoing restoration and conservation projects with data on biodiversity and land use may pave the way for a more careful consideration of natural resources in decision making. Recommendations are provided in writing, presented in live events, and discussed and refined during stakeholder consultations. These efforts can also support the development of more transparent and democratic decisionmaking processes for water management.

The decision support tool developed by the SuMaRiO project in China supports institutions at the national and provincial level in testing different scenarios of land and water use (Siew et al. 2014). The tool has mainly educational purpose and allows the involved institutions to better understand possible impacts of land-use decisions on ES. Although it is a simplification of the watershed, the tool supports institutions in developing an improved understanding of the complexity of the system and general trends across the watershed.

Enhancing the use of home gardens has been identified by the SuLaMa project in Madagascar as a viable option that improves income of local households and increases resilience to environmental disturbances, e.g., pests and droughts. Local acceptance of this strategy is expected to be high because it builds on existing land-use practices and benefits women in particular. With regard to potential alternative strategies for crop and fodder production, more investigation is needed to get a better understanding of possible adverse impacts, e.g., an increase in livestock production could cause conflicts over scarce water resources. Modern farming practices were previously introduced by development organizations but subsequently abandoned for the lack of local acceptance, indicating complex social-ecological challenges involved in establishing alternative land-use practices.

Educating and training farmers and government officials in ecological engineering is identified by the LEGATO project as an important component of supporting rice farmers in Vietnam.
"Farmer field schools" and "entertainment education" including soap opera episodes on radio and TV (Escalada et al. 1999, Heong et al. 2008, 2014) proved to be effective tools for education about the practices of ecological engineering. Furthermore, based on the ES assessment, policy advice was developed for regional and national government departments to better integrate knowledge on biodiversity and ES in rice farming policies. Provincial administrations insisted on the participation of representatives of the agricultural administration in farmer training to build capacity for repeating the training on a province-wide scale. In addition, the project participants were frequently consulted for advice on provincial development plans. Despite this success, the generated information can become irrelevant to decision makers, for example, if other issues on the political agenda become more relevant, or in case of mismatch of competencies between project partners.

\section{DISCUSSION AND CONCLUSION}

Initiatives like the SLM Program and PECS aim at applying ES assessments to inform decisions on specific land-use problems. However, simply generating ES information does not guarantee its relevance for decision making (Laurans et al. 2013). Often science-driven ES assessments focus only on biophysical functions (Honey-Rosés and Pendleton 2013), ignoring diversity in ES benefits and information needs by decision makers. Social and political processes in the provision and distribution of ES and resulting social, distributional, and economic impacts are often not analyzed. The presented problem-oriented approach was developed to better target ES assessments to specific information needs by decision makers. The approach builds on the analysis of empirical experience of four place-based ES assessments (Fig. 1) and existing ES frameworks (Fig. 2).

The presented approach stresses the need to: (a) identify land-use problems (step 1) and related information needs by decision makers (step 3) from the outset of the assessment process, and (b) 
focus on decision-relevant ES information throughout the assessment process (step 2 and step 4).

Step 1 and step 3 are useful for focusing ES assessments on landuse problems from a stakeholder point of view within a particular local or regional decision context. This promotes both engagement of relevant stakeholders and the building of trust between stakeholder groups. Trust among stakeholders is important for sharing knowledge but also for acknowledging relevant knowledge gaps. This includes, for example, local knowledge on diversifying crop production as a means of building resilience to droughts and pests in Madagascar (SuLaMa, Fig. 3 ), and knowledge on the relevance of local practices for enhancing resistance of rice farming to pests in Vietnam (LEGATO, Fig. 4).

Targeting the assessments on priorities relevant for decision making (step 2 and step 4) helps to integrate ES information into ongoing policy processes (step 5). For example, the SuMaRiO project (Fig. 6) informs the development of the five-year-plan for the Tarim Basin in China about ES trade-offs involved in cotton production. Having a clear focus on decision-relevant land-use problems from the outset of the assessment enhances the probability that the generated ES information will be integrated in the decision process.

The presented approach also facilitates the establishment of partnerships with decision-relevant institutions, the development of a common understanding of the issues at stake, and the building of trust between stakeholders involved in the assessment. For example, it enabled the INNOVATE project (Fig. 5) to establish a close working relationship with the Watershed Committee of the São Francisco River in Brazil, allowing effective communication of information needs of decision makers to the scientists conducting the ES assessment. This also allows the transfer of assessment findings back to relevant stakeholders and decision makers, highlighting where regional and national policies and development priorities override interests of local land user.

The clarity of problems and information needs is also important to agree on assessment goals and the type of decision support that an ES assessment can realistically deliver within a given context and with available resources. The process of codesign with stakeholders allows identifying opportunities for the ES assessment to provide a meaningful contribution to a specific decision-making process. This is important to clarify limitations and avoid overly ambitious expectations. ES assessments can trigger changes in decision making, in particular, if they are linked to ongoing decision-making processes. The development of decision support tools and guidelines can be useful in promoting this process. Nevertheless, the impact of technical decision support tools should not be overestimated because decision processes are often complex negotiations dependent on multiple factors that are beyond the scope of an ES assessment.

ES assessments are unlikely to deliver ultimate solutions to the identified problems. When ES assessments become part of a political process, they can contribute to solutions but also trigger new conflicts. For example, the INNOVATE project identified that the ES assessment can help making decisions on water management more transparent and thereby facilitate stakeholder involvement in water management. However, more transparency in decision making is not always wanted by all stakeholders or decision makers.

Nonetheless, achieving a shared understanding of the role of ES within the social-ecological context can already be beneficial for the decision-making process. Designing ES assessments is a learning process where the design is refined and re-adjusted in the course of the assessment process and in response to newly acquired knowledge. To paraphrase Albert Einstein, assessments should be as simple as possible, but no simpler. We recognize that step-wise approaches are a simplification of the process required to fully understand the complexities involved in social-ecological systems (Rogers et al. 2013). However, our approach is meant to provide pragmatic guidance for making ES assessments more policy-relevant by focusing the design of assessments on particular land-use problems, stakeholder priorities, and information needs to explore options for more sustainable land management.

Responses to this article can be read online at: http://www.ecologyandsociety.org/issues/responses. $\mathrm{php} / 7804$

\section{Acknowledgments:}

We would like to thank all participants and stakeholders involved in the projects of the Sustainable Land Management Program for sharing their experiences and insights, and the German Federal Ministry of Education and Research - BMBF for funding the Program. J.F, R.S., T.V. were funded by BMBF grant 01 LL0901 A: GLUES. J.B., R.F., S.K., D.K. were funded by BMBF grant $A Z$ : LLA2-014: SuLaMa. S.H., J.S., J.S, V.T. were funded by BMBF grant FKZ01 LL0917A-01 LL0917O: LEGATO. M.K. was funded by BMBF grant 01LL0911A: COMTESS. C.R. was funded by BMBF grant 01LL0918L: SuMaRiO. M.S.S. was funded by BMBF grant 01LL0904A: INNOVATE. H.W. was funded by the Helmholtz Centre for Environmental Research - UFZ. We thank two anonymous reviewers for constructive comments on a previous version of this publication. This paper is a contribution to the Programme on Ecosystem Change and Society (PECS; http:/l www.pecs-science.org/).

\section{LITERATURE CITED}

Abson, D. J., and J. Hanspach. 2014. Response to Turnhout et al. 's rethinking biodiversity: from goods and services to "living with." Conservation Letters 7:334-335. http://dx.doi.org/10.1111/ conl.12059

Abson, D. J., and M. Termansen. 2011. Valuing ecosystem services in terms of ecological risks and returns. Conservation Biology 25(2):250-258. http://dx.doi.org/10.1111/j.1523-1739.2010.01623. $\underline{\mathrm{X}}$

Abson, D. J., H. von Wehrden, S. Baumgärtner, J. Fischer, J. Hanspach, W. Härdtle, H. Heinrichs, A. M. Klein, D. J. Lang, P. Martens, and D. Walmsley. 2014. Ecosystem services as a boundary object for sustainability. Ecological Economics 103:29-37. http://dx.doi.org/10.1016/j.ecolecon.2014.04.012 
Bagstad, K. J., D. J. Semmens, S. Waage, and R. Winthrop. 2013. A comparative assessment of decision-support tools for ecosystem services quantification and valuation. Ecosystem Services 5:27-39. http://dx.doi.org/10.1016/j.ecoser.2013.07.004

Bruns, E., D. Ohlhorst, B. Wenzel, and J. Köppel. 2011. Renewable energies in Germany's electricity market: a biography of the innovation process. Springer Netherlands, Dordrecht, The Netherlands. http://dx.doi.org/10.1007/978-90-481-9905-1

Carpenter, S. R., C. Folke, A. Norström, O. Olsson, L. Schultz, B. Agarwal, P. Balvanera, B. Campbell, J. C. Castilla, W. Cramer, R. DeFries, P. Eyzaguirre, T. P. Hughes, S. Polasky, Z. Sanusi, R. Scholes, and M. Spierenburg. 2012. Program on ecosystem change and society: an international research strategy for integrated social-ecological systems. Current Opinion in Environmental Sustainability 4(1):134-138. http://dx.doi.org/10.1016/j.cosust.2012.01.001

Carpenter, S. R., H. A. Mooney, J. Agard, D. Capistrano, R. S. DeFries, S. Diaz, T. Dietz, A. K. Duraiappah, A. Oteng-Yeboah, H. M. Pereira, C. Perrings, W. V. Reid, J. Sarukhan, R. J. Scholes, and A. Whyte. 2009. Science for managing ecosystem services: beyond the Millennium Ecosystem Assessment. Proceedings of the National Academy of Sciences 106(5):1305-1312. http://dx. doi.org/10.1073/pnas.0808772106

Chan, K. M. A., A. D. Guerry, P. Balvanera, S. Klain, T. Satterfield, X. Basurto, A. Bostrom, R. Chuenpagdee, R. Gould, B. S. Halpern, N. Hannahs, J. Levine, B. Norton, M. Ruckelshaus, R. Russell, J. Tam, and U. Woodside. 2012a. Where are cultural and social in ecosystem services? A framework for constructive engagement. BioScience 62(8):744-756. http://dx.doi.org/10.1525/ bio.2012.62.8.7

Chan, K. M. A., T. Satterfield, and J. Goldstein. $2012 b$. Rethinking ecosystem services to better address and navigate cultural values. Ecological Economics 74:8-18. http://dx.doi. org/10.1016/j.ecolecon.2011.11.011

Christie, M., I. Fazey, R. Cooper, T. Hyde, and J. O. Kenter. 2012. An evaluation of monetary and non-monetary techniques for assessing the importance of biodiversity and ecosystem services to people in countries with developing economies. Ecological Economics 83:67-78. http://dx.doi.org/10.1016/j.ecolecon.2012.08.012

Cowling, R. M., B. Egoh, A. T. Knight, P. J. O’Farrell, B. Reyers, M. Rouget, D. J. Roux, A. Welz, and A. Wilhelm-Rechman. 2008. An operational model for mainstreaming ecosystem services for implementation. Proceedings of the National Academy of Sciences 105(28):9483-9488. http://dx.doi.org/10.1073/pnas.0706559105

Crossman, N. D., B. Burkhard, S. Nedkov, L. Willemen, K. Petz, I. Palomo, E. G. Drakou, B. Martín-Lopez, T. McPhearson, K. Boyanova, R. Alkemade, B. Egoh, M. B. Dunbar, and J. Maes. 2013. A blueprint for mapping and modelling ecosystem services. Ecosystem Services 4:4-14. http://dx.doi.org/10.1016/j.ecoser.2013.02.001

Daily, G. C., S. Polasky, J. Goldstein, P. M. Kareiva, H. A. Mooney, L. Pejchar, T. H. Ricketts, J. Salzman, and R. Shallenberger. 2009. Ecosystem services in decision making: time to deliver. Frontiers in Ecology and the Environment 7(1):21-28. http://dx.doi.org/10.1890/080025

de Groot, R. S., R. Alkemade, L. Braat, L. Hein, and L. Willemen. 2010. Challenges in integrating the concept of ecosystem services and values in landscape planning, management and decision making. Ecological Complexity 7(3):260-272. http://dx.doi. org/10.1016/j.ecocom.2009.10.006

Egoh, B., B. Reyers, M. Rouget, M. Bode, and D. M. Richardson. 2009. Spatial congruence between biodiversity and ecosystem services in South Africa. Biological Conservation 142(3):553-562. http://dx.doi.org/10.1016/j.biocon.2008.11.009

Eppink, F. V., A. Werntze, S. Mäs, A. Popp, and R. Seppelt. 2012. Land management and ecosystem services: how collaborative research programmes can support better policies. GAIA 21 (1):55-63.

Escalada, M. M., K. L. Heong, N. H. Huan, and V. Mai. 1999. Communication and behavior change in rice farmers' pest management: the case of using mass media in Vietnam. Journal of Applied Communications 83(1):7-26.

Feike, T., Y. Mamitimin, L. Li, and R. Doluschitz. 2015. Development of agricultural land and water use and its driving forces along the Aksu and Tarim River, P.R. China. Environmental Earth Sciences 73:517-531. http://dx.doi.org/10.1007/s12665-014-3108$\underline{x}$

Feld, C. K., P. M. Da Silva, J. P. Sousa, F. De Bello, R. Bugter, U. Grandin, D. Hering, S. Lavorel, O. Mountford, I. Pardo, M. Pärtel, J. Römbke, L. Sandin, K. B. Jones, and P. Harrison. 2009. Indicators of biodiversity and ecosystem services: a synthesis across ecosystems and spatial scales. Oikos 118(12):1862-1871. http://dx.doi.org/10.1111/j.1600-0706.2009.17860.x

Fisher, B., R. K. Turner, and P. Morling. 2009. Defining and classifying ecosystem services for decision making. Ecological Economics 68(3):643-653. http://dx.doi.org/10.1016/j. ecolecon.2008.09.014

Fontana, V., A. Radtke, V. Bossi Fedrigotti, U. Tappeiner, E. Tasser, S. Zerbe, and T. Buchholz. 2013. Comparing land-use alternatives: using the ecosystem services concept to define a multi-criteria decision analysis. Ecological Economics 93:128-136. http://dx.doi.org/10.1016/j.ecolecon.2013.05.007

Garrick, D., M. A. Siebentritt, B. Aylward, C. J. Bauer, and A. Purkey. 2009. Water markets and freshwater ecosystem services: policy reform and implementation in the Columbia and MurrayDarling Basins. Ecological Economics 69(2):366-379. http://dx. doi.org/10.1016/j.ecolecon.2009.08.004

Goldman, R. L., H. Tallis, P. Kareiva, and G. C. Daily. 2008. Field evidence that ecosystem service projects support biodiversity and diversify options. Proceedings of the National Academy of Sciences 105(27):9445-9448. http://dx.doi.org/10.1073/pnas.0800208105

Goldstein, J. H., G. Caldarone, T. K. Duarte, D. Ennaanay, N. Hannahs, G. Mendoza, S. Polasky, S. Wolny, and G. C. Daily. 2012. Integrating ecosystem-service tradeoffs into land-use decisions. Proceedings of the National Academy of Sciences 109 (19):7565-7570. http://dx.doi.org/10.1073/pnas.1201040109

Görg, C., J. H. Spangenberg, V. Tekken, B. Burkhard, D. T. Truong, M. Escalada, K. Luen Heong, G. Arida, L. V. Marquez, J. V. Bustamante, H. Van Chien, T. Klotzbücher, A. Marxen, N. Hung Manh, N. Van Sinh, S. (Bong) Villareal, and J. Settele. 2014. Engaging local knowledge in biodiversity research: experiences from large inter- and transdisciplinary projects. Interdisciplinary 
Science Reviews 39(4):323-341. http://dx.doi.org/10.1179/0308018814z.00000000095

Haines-Young, R., and M. Potschin. 2012. Common international classification of ecosystem services (CICES): consultation on Version 4, August-December 2012. EEA Framework Contract No: EEA/IEA/09/003

Heong, K. L., M. M. Escalada, H. V Chien, and L. Q. Cuong. 2014. Restoration of rice landscape biodiversity by farmers in Vietnam through education and motivation using media. S.A.P. I.EN.S 7:1-7.

Heong, K. L., M. M. Escalada, N. H. Huan, V. H. Ky Ba, P. V. Quynh, L. V. Thiet, and H. V. Chien. 2008. Entertainmenteducation and rice pest management: a radio soap opera in Vietnam. Crop Protection 27(10):1392-1397. http://dx.doi. org/10.1016/j.cropro.2008.05.010

Honey-Rosés, J., and L. H. Pendleton. 2013. A demand driven research agenda for ecosystem services. Ecosystem Services 5:160-162. http://dx.doi.org/10.1016/j.ecoser.2013.04.007

Jax, K., D. N. Barton, K. M. A. Chan, R. de Groot, U. Doyle, U. Eser, C. Görg, E. Gómez-Baggethun, Y. Griewald, W. Haber, R. Haines-Young, U. Heink, T. Jahn, H. Joosten, L. Kerschbaumer, H. Korn, G. W. Luck, B. Matzdorf, B. Muraca, C. Neßhöver, B. Norton, K. Ott, M. Potschin, F. Rauschmayer, C. von Haaren, and S. Wichmann. 2013. Ecosystem services and ethics. Ecological Economics 93:260-268. http://dx.doi.org/10.1016/j.ecolecon.2013.06.008

Krysanova, V., M. Wortmann, T. Bolch, B. Merz, D. Duethmann, J. Walter, S. Huang, J. Tong, S. Buda, and Z. W. Kundzewicz. 2015. Analysis of current trends in climate parameters, river discharge and glaciers in the Aksu River basin (Central Asia). Hydrological Sciences Journal 60(4):566-590. http://dx.doi. org/10.1080/02626667.2014.925559

Laurans, Y., A. Rankovic, R. Billé, R. Pirard, and L. Mermet. 2013. Use of ecosystem services economic valuation for decision making: questioning a literature blindspot. Journal of Environmental Management 119:208-219. http://dx.doi.org/10.1016/ j.jenvman.2013.01.008

Liekens, I., S. Broekx, N. Smeets, J. Staes, K. Van der Biest, M. Schaafsma, L. De Nocker, P. Meire, and T. Cerulus. 2013. The ecosystem services valuation tool and its future developments. Pages 249-262 in S. Jacobs, N. Dendoncker, and H. Keune, editors. Ecosystem services: global issues, local practices. First edition. Elsevier, Boston, Massachusetts, USA. http://dx.doi.org/10.1016/ b978-0-12-419964-4.00019-6

Limburg, K. E., R. V. O’Neill, R. Costanza, and S. Farber. 2002. Complex systems and valuation. Ecological Economics 41 (3):409-420. http://dx.doi.org/10.1016/s0921-8009(02)00090-3

Martinez-Harms, M. J., B. A. Bryan, P. Balvanera, E. A. Law, J. R. Rhodes, H. P. Possingham, and K. A. Wilson. 2015. Making decisions for managing ecosystem services. Biological Conservation 184:229-238. http://dx.doi.org/10.1016/j.biocon.2015.01.024

Martín-López, B., E. Gómez-Baggethun, M. García-Llorente, and C. Montes. 2014. Trade-offs across value-domains in ecosystem services assessment. Ecological Indicators 37:220-228. http://dx.doi.org/10.1016/j.ecolind.2013.03.003
Millennium Ecosystem Assessment. 2005. Ecosystems and human well-being: synthesis. Island Press, Washington, D.C., USA.

Milner-Gulland, E. J., M. Fisher, S. Browne, K. H. Redford, M. Spencer, and W. J. Sutherland. 2010. Do we need to develop a more relevant conservation literature? Oryx 44(01):1-2. http://dx. doi.org/10.1017/S0030605309991001

Nelson, E., G. Mendoza, J. Regetz, S. Polasky, H. Tallis, D. R. Cameron, K. M. A. Chan, G. C. Daily, J. Goldstein, P. M. Kareiva, E. Lonsdorf, R. Naidoo, T. H. Ricketts, and M. R. Shaw. 2009. Modeling multiple ecosystem services, biodiversity conservation, commodity production, and tradeoffs at landscape scales. Frontiers in Ecology and the Environment 7(1):4-11. http://dx.doi. org/10.1890/080023

Ntshotsho, P., H. E. Prozesky, K. J. Esler, and B. Reyers. 2015. What drives the use of scientific evidence in decision making? The case of the South African Working for Water program. Biological Conservation 184:136-144. http://dx.doi.org/10.1016/j.biocon.2015.01.021

Ostrom, E. 2007. A diagnostic approach for going beyond panaceas. Proceedings of the National Academy of Sciences 104 (39):15181-15187. http://dx.doi.org/10.1073/pnas.0702288104

Ostrom, E. 2009. A general framework for analyzing sustainability of social-ecological systems. Science 325 (5939):419-22. http://dx.doi.org/10.1126/science.1172133

Petter, M., S. Mooney, S. M. Maynard, A. Davidson, M. Cox, and I. Horosak. 2012. A methodology to map ecosystem functions to support ecosystem services assessments. Ecology and Society 18(1): 31. http://dx.doi.org/10.5751/es-05260-180131

Pischke, F., and M. Cashmore. 2006. Decision-oriented environmental assessment: an empirical study of its theory and methods. Environmental Impact Assessment Review 26 (7):643-662. http://dx.doi.org/10.1016/j.eiar.2006.06.004

Plieninger, T., S. Dijks, E. Oteros-Rozas, and C. Bieling. 2013. Assessing, mapping, and quantifying cultural ecosystem services at community level. Land Use Policy 33:118-129. http://dx.doi. org/10.1016/j.landusepol.2012.12.013

Rathwell, K. J., and G. D. Peterson. 2012. Connecting social networks with ecosystem services for watershed governance: a social-ecological network perspective highlights the critical role of bridging organizations. Ecology and Society 17(2): 24. http:// dx.doi.org/10.5751/es-04810-170224

Raudsepp-Hearne, C., G. D. Peterson, and E. M. Bennett. 2010. Ecosystem service bundles for analyzing tradeoffs in diverse landscapes. Proceedings of the National Academy of Sciences 107 (11):5242-5247. http://dx.doi.org/10.1073/pnas.0907284107

Reed, M. S., K. Hubacek, A. Bonn, T. P. Burt, J. Holden, L. C. Stringer, N. Beharry-Borg, S. Buckmaster, D. Chapman, P. J. Chapman, G. D. Clay, S. J. Cornell, A. J. Dougill, A. C. Evely, E. D. G. Fraser, N. Jin, B. J. Irvine, M. J. Kirkby, W. E. Kunin, C. Prell, C. H. Quinn, B. Slee, S. Stagl, M. Termansen, S. Thorp, and F. Worrall. 2013. Anticipating and managing future trade-offs and complementarities between ecosystem services. Ecology and Society 18(1): 5. http://dx.doi.org/10.5751/es-04924-180105

Reyers, B., R. Biggs, G. S. Cumming, T. Elmqvist, A. P. Hejnowicz, and S. Polasky. 2013. Getting the measure of ecosystem services: 
a social-ecological approach. Frontiers in Ecology and the Environment 11(5):268-273. http://dx.doi.org/10.1890/120144

Reyers, B., D. J. Roux, and P. J. O'Farrell. 2010. Can ecosystem services lead ecology on a transdisciplinary pathway? Environmental Conservation 37(4):501-511. http://dx.doi.org/10.1017/ $\underline{\mathrm{S} 0376892910000846}$

Rode, J., E. Gómez-Baggethun, and T. Krause. 2015. Motivation crowding by economic incentives in conservation policy: a review of the empirical evidence. Ecological Economics 117:270-282. http://dx.doi.org/10.1016/j.ecolecon.2014.11.019

Rogers, K. H., R. Luton, H. Biggs, R. Biggs, S. Blignaut, A. G. Choles, C. G. Palmer, and P. Tangwe. 2013. Fostering complexity thinking in action research for change in social-ecological systems. Ecology and Society 18(2): 31. http://dx.doi.org/10.5751/ ES-05330-180231

Ruckelshaus, M., E. McKenzie, H. Tallis, A. Guerry, G. Daily, P. Kareiva, S. Polasky, T. Ricketts, N. Bhagabati, S. A. Wood, and J. Bernhardt. 2015. Notes from the field: lessons learned from using ecosystem service approaches to inform real-world decisions. Ecological Economics 115:11-21. http://dx.doi. org/10.1016/j.ecolecon.2013.07.009

Rumbaur, C., N. Thevs, M. Disse, M. Ahlheim, A. Brieden, B. Cyffka, D. Duethmann, T. Feike, O. Frör, P. Gärtner, Ü. Halik, J. Hill, M. Hinnenthal, P. Keilholz, B. Kleinschmit, V. Krysanova, M. Kuba, S. Mader, C. Menz, H. Othmanli, S. Pelz, M. Schroeder, T. F. Siew, V. Stender, K. Stahr, F. M. Thomas, M. Welp, M. Wortmann, X. Zhao, X. Chen, T. Jiang, J. Luo, H. Yimit, R. Yu, X. Zhang, and C. Zhao. 2015. Sustainable management of river oases along the Tarim River (SuMaRiO) in northwest China under conditions of climate change. Earth System Dynamics 6 (1):83-107. http://dx.doi.org/10.5194/esd-6-83-2015

Saarikoski, H., J. Mustajoki, and M. Marttunen. $2013 a$. Participatory multi-criteria assessment as 'opening up' vs. 'closing down' of policy discourses: a case of old-growth forest conflict in Finnish Upper Lapland. Land Use Policy 32:329-336. http://dx. doi.org/10.1016/i.landusepol.2012.11.003

Saarikoski, H., K. Raitio, and J. Barry. 2013b. Understanding 'successful' conflict resolution: policy regime changes and new interactive arenas in the Great Bear Rainforest. Land Use Policy 32:271-280. http://dx.doi.org/10.1016/j.landusepol.2012.10.019

Schröter, M., E. H. van der Zanden, A. P. E. van Oudenhoven, R. P. Remme, H. M. Serna-Chavez, R. S. de Groot, and P. Opdam. 2014. Ecosystem services as a contested concept: a synthesis of critique and counter-arguments. Conservation Letters 7 (6):514-523. http://dx.doi.org/10.1111/conl.12091

Seppelt, R., C. F. Dormann, F. V. Eppink, S. Lautenbach, and S. Schmidt. 2011. A quantitative review of ecosystem service studies: approaches, shortcomings and the road ahead. Journal of Applied Ecology 48(3):630-636. http://dx.doi.org/10.1111/j.1365-2664.2010.01952. $\underline{\mathrm{X}}$

Settele, S., I. Kühn, S. Klotz, G. Arida, E. Bergmeier, B. Burkhard, J. Bustamante, D. T. Truong, M. Escalada, C. Görg, V. Grescho, H. Van Chien, K. Heong, N. Hirneisen, S. Hotes, R. Jahn, T. Klotzbücher, G. Marion, L. Marquez, A. Marxen, R. Moritz, F. Müller, N. Van Sinh, J. Ott, L. Penev, B. Rodriguez-Labajos, M.
Schädler, S. Scheu, R. Seppelt, P. Stoev, T. Tscharntke, V. Tekken, K. Thonicke, D. Vetterlein, S. Vidal, S. Villareal, W. W. Weisser, C. Westphal, M. Wiemers, and J. Spangenberg. 2013. Kulturlandschaftsforschung in Südostasien - das LEGATOProjekt. Berichte. Geographie und Landeskunde 87(3):315-323.

Siegmund-Schultze, M., V. Rodorff, J. Köppel, and M. do Carmo Sobral. 2015. Paternalism or participatory governance? Efforts and obstacles in implementing the Brazilian water policy in a large watershed. Land Use Policy 48:120-130. http://dx.doi. org/10.1016/j.landusepol.2015.05.024

Siew, T. F., P. Döll, and H. Yimit. 2014. Experiences with a transdisciplinary research approach for integrating ecosystem services into water management in northwest China. Pages 303-319 in A. Bhaduri, J. Bogardi, J. Leentvaar, and S. Marx, editors. The global water system in the Anthropocene. Springer International, Switzerland. http://dx.doi.org/10.1007/978-3-319$\underline{-07548-8 \quad 20}$

Sijtsma, F. J., C. M. van der Heide, and A. van Hinsberg. 2013. Beyond monetary measurement: how to evaluate projects and policies using the ecosystem services framework. Environmental Science \& Policy 32:14-25. http://dx.doi.org/10.1016/j.envsci.2012.06.016

Sorg, A., T. Bolch, M. Stoffel, O. Solomina, and M. Beniston. 2012. Climate change impacts on glaciers and runoff in Tien Shan (Central Asia). Nature Climate Change 2(10):725-731. http://dx. doi.org/10.1038/nclimate1592

Spangenberg, J. H., C. Görg, D. T. Truong, V. Tekken, J. V. Bustamante, and J. Settele. 2014a. Provision of ecosystem services is determined by human agency, not ecosystem functions. Four case studies. International Journal of Biodiversity Science, Ecosystem Services \& Management 10(1):40-53.

Spangenberg, J. H., C. von Haaren, and J. Settele. 2014b. The ecosystem service cascade: further developing the metaphor. Integrating societal processes to accommodate social processes and planning, and the case of bioenergy. Ecological Economics 104:22-32. http://dx.doi.org/10.1016/j.ecolecon.2014.04.025

Tekken, V., and J. Settele. 2014. Instrumente zur nachhaltigen Agrarlandschafts- Optimierung: Ecological Engineering als Ansatz zur Konstruktion nachhaltiger Agrarlandschaften in Reisanbaugebieten Südost-Asiens. Pages 173-186 in G. Hartung and T. Kirchhoff, editors. Welche Natur brauchen wir? Analyse einer anthropologischen Grundproblematik des 21. Jahrhunderts. Verlag Karl Alber in der Verlag Herder GmbH, Freiburg / München, Germany.

The Economics of Ecosystems and Biodiversity (TEEB). 2010. Mainstreaming the economics of nature: a synthesis of the approach, conclusions and recommendations of TEEB. P. Sukhdev, H. Wittmer, C. Schröter-Schlaack, C. Nesshöver, J. Bishop, P. ten Brink, H. Gundimeda, P. Kumar, and B. Simmons, editors. TEEB, Geneva, Switzerland.

The Economics of Ecosystems and Biodiversity (TEEB). 2012. The economics of ecosystems and biodiversity in local and regional policy and management. H. Wittmer and $\mathrm{H}$. Gundimeda, editors. Earthscan, London, UK.

Thevs, N., S. Zerbe, Y. Kyosev, A. Rozi, B. Tang, N. Abdusalih, and Z. Novitskiy. 2012. Apocynum venetum L. and Apocynum 
pictum Schrenk ( Apocynaceae ) as multi-functional and multiservice plant species in Central Asia : a review on biology, ecology, and utilization. Journal of Applied Botany and Food Quality 85:159-167.

Turnhout, E., C. Waterton, K. Neves, and M. Buizer. 2013. Rethinking biodiversity: from goods and services to "living with." Conservation Letters 6:154-161. http://dx.doi.org/10.1111/ j.1755-263x.2012.00307.x

Viglizzo, E. F., J. M. Paruelo, P. Laterra, and E. G. Jobbágy. 2012. Ecosystem service evaluation to support land-use policy. Agriculture, Ecosystems and Environment 154:78-84. http://dx. doi.org/10.1016/j.agee.2011.07.007

Villa, F., B. Voigt, and J. D. Erickson. 2014. New perspectives in ecosystem services science as instruments to understand environmental securities. Philosophical Transactions of the Royal Society of London. Series B, Biological Sciences 369 (1639):20120286. http://dx.doi.org/10.1098/rstb.2012.0286

Wilkinson, C., T. Saarne, G. D. Peterson, and J. Colding. 2013. Strategic spatial planning and the ecosystem services conceptan historical exploration. Ecology and Society 18(1): 37 . http:// dx.doi.org/10.5751/es-05368-180137 